\title{
WATER AND THE SEARCH FOR PUBLIC HEALTH IN LONDON IN THE EIGHTEENTH AND NINETEENTH CENTURIES
}

\author{
by
}

\begin{abstract}
ANNE HARDY*
THE history of water supplies in England is a poorly documented subject. Although various accounts of the history of water technology, and learned articles on the political and administrative aspects of water supply have been written, the history of water in relation to public health remains largely unexplored. As this is, especially concerning the nineteenth century, a voluminous subject, the present paper attempts no more than a broad survey of the process by which water came to be recognized as a vital element in public health, of the gradual discovery and application of criteria for water purity, and of the means by which supplies satisfactory in quantity and quality were obtained. The roots of the modern concern with environment and its effect on health lie in the eighteenth century, and in this period the first indications of interest in the quality and physical effects of water are found. Health and cleanliness were treated as personal matters in the eighteenth and earlier nineteenth centuries: in the first parliamentary inquiry into water quality in 1828 there is little evidence of any wider concern with the health of the general population. It was only in the later $1830 \mathrm{~s}$ and 1840s that the idea of public health in its widest, or modern, sense began to gain currency, and only in the second half of the nineteenth century that the term came to have, for certain social elements, a further dimension of public morality as well. It is against this background of movement from an individual to a social concern that the development of modern standards of water services must be viewed. The evolution of the public health idea during this period is reflected in the nature and quantity of primary sources. These are sparse for the eighteenth century, but plentiful by the second half of the nineteenth. The sources for the latter period are also more familiar, and therefore have been treated more cavalierly in this paper: the intention has been more to illuminate less familiar aspects of the water question than to present a definitive history. The geographical scope of this account has been limited to London, partly for convenience, but also because the experience of the capital was crucial in influencing the development of medical and legislative concern with water.
\end{abstract}

The history of London is intimately linked to that of the river Thames. The city owed its foundation to the river, and from then, until within the last hundred years, the river remained a cornerstone of the city's economy and the focal point of England's

*Anne Hardy, MA, DPhil, Nuffield College, Oxford OX1 INF.

A version of this paper was first delivered to the fifteenth annual conference of the Institute for Economic History F. Datini, Prato, Italy, in April 1983. 


\section{Water and the search for public health in London}

trade and international communications. The river provided transport, recreation facilities, food, and water supplies. It became, from the sixteenth century at least, a cause for patriotic celebration. The poet Edmund Spenser's "Sweet Thames" then ran between marshy banks on which grew rushes and yellow iris, and in which water animals and birds made their homes. Green meadows lay between the cities of London and Westminster, and trim gardens bordered both fields and river. ${ }^{1}$ Tudor London covered hardly more than the present area of the City of London, and in the two centuries that followed, the city's growth, although rapid by contemporary standards, was slight compared to the massive expansion that took place in the years after 1800 . By 1820 , London extended towards limits that must have seemed almost inconceivable: Vauxhall Bridge, Victoria, Edgware Road, Regents Park, City Road, Limehouse, Rotherhithe, and Lambeth. ${ }^{2}$ The river remained crucial to this development, and was recognized as such. "The Thames", wrote a seventeenth-century observer "is the privileged place for fish and ships, the glory and wealth of the city, the highway to the sea, the bringer-in of wealth and strangers ..."; while his eighteenth-century successor named it "that great ornament and support of our kingdom in general, but particularly of our metropolis". ${ }^{3}$

Yet the beauty of the river, and the wealth which it brought the city, were not complemented by more domestic virtues. It was difficult to draw water for household use from the river, and until the early seventeenth century, London was largely supplied with water from shallow wells, which were sunk both in public places and in the yards and gardens of private establishments. ${ }^{4}$ Although the Thames had numerous tributaries, a number of which ran through the city, these were popularly found so useful for the disposal of rubbish that they became polluted and unusable from an early date. ${ }^{5}$ From the thirteenth century at least, Londoners were, in the words of the sixteenth-century antiquary John Stow, seeking for sweet waters abroad. ${ }^{6}$ The first patent to bring water into the city by lead pipes from Tyburn was issued in 1236; this water was to be used, it is interesting to note, "for the poor to drink, and for the rich to dress their meat". The first public cistern, the Great Conduit in West Cheap, was begun in 1285 , to store the water thus brought from Paddington. ${ }^{7}$ By the end of the sixteenth century, some twenty conduits existed, three of which drew their supply from the Thames, and three of which are still commemorated today in the names of Great Conduit, Lamb's Conduit, and White's Conduit Streets. The inhabitants of London could either fetch their water direct from the conduits, or buy it from the water-sellers, who transported the vital commodity into the surrounding streets. ${ }^{8}$

The later sixteenth century saw the emergence of two new features in the London supply system, first, the mechanical pumping of water from the river, and second, its

\footnotetext{
${ }^{1}$ R. J. Mitchell and M. D. R. Leys, A history of London life, London, Pelican Books, 1963. pp. 15-16, 154.

${ }^{2}$ R. S. R. Fitter, London's natural history, London, Collins, 1954, p. 64

${ }^{3}$ Mitchell and Leys, op. cit., note 1 above, p. 154; Charles Lucas, Essay on waters, 3 vols., London, A. D. Millar, 1756, p. 127.

4 Royal Commission on Rivers Pollution, sixth report, BPP 1874 XXXIII, p. 622

${ }^{3}$ L. B. Wood, The restoration of the tidal Thames, London, Adam Hilger, 1982, pp. 7-9.

- John Stow, Survey of London, London, Everyman, 1970, p. 17.

'Ibid.

Wood, op. cit., note 5 above, p. 11 .
} 


\section{Anne Hardy}

conveyance directly, by means of lead pipes, into private homes. Both these innovations were introduced by the Dutchman, Peter Morris, who established the London Bridge pumping station in 1582.' The principle of commercial conveyance of domestic water supplies was thus established (Morris's innovation was soon copied, for example by Bevis Bulmer in 1594), but the quality of Thames water was already a matter of adverse comment. One Italian visitor, for instance, remarked that it was "hard, turbid, and stinking". ${ }^{10}$ Early in the seventeenth century, Sir Hugh Middleton was inspired to propose the conveyance of sweet water to London by aqueduct from the unpolluted springs of the Lea River in Hertfordshire. This work was completed in 1613, and through the seventeenth and eighteenth centuries a number of other companies were established, each working for profit within an exclusive area. ${ }^{11}$ By 1828 , nine London companies served some 164,000 tenants, in a city containing about 200,000 houses, and a population of about $1,500,000 .^{12}$

The source of supply for all the new water companies, except for the New River, was the Thames, although during the eighteenth century, the New River supplied more water to London than all the other companies put together. ${ }^{13}$ Complaints as to the quality of London's water were few, if any, before the early nineteenth century. The reasons for this are various. The wealthy and articulate classes, who benefited from the piped company supplies, rarely drank water undiluted; in their houses, water was commonly used for washing and cooking, perhaps for drinking by female servants. The continued widespread practice of home brewing, combined with the growth of the London brewing industry, and the great spread of alehouses, inns, and taverns from the sixteenth century, meant that beer had, by this period, come to be the normal beverage of a wide section of the population. ${ }^{14}$ Further, people were accustomed to the turbid water they received and seem to have accepted it as a matter of course, and found ways of minimizing any inconvenience it caused. The maids of one great house in Portman Square, for example, found that the household washing would not come clean in company water; they were obliged to give it a final, bleaching rinse in hard pump water. ${ }^{15}$ Nor was it customary to associate illness with water: as $\mathrm{Dr}$ Yeates, himself convinced that "the repeated introduction into the stomach of injurious impurities would undermine the health", admitted. He could not recollect any of his patients attributing their illness to the use of company water: ". . it is not likely that they would, for the effect is not so immediate and direct as to call their attention to the cause, it therefore escapes their notice."16

\footnotetext{
- Ibid. The story of the New River Company, and the evolution of the company water supply system is told by a number of authorities, e.g., H. W. Dickinson, Water supply of Greater London, London, Newcomen Society, 1954, p. 16; W. M. Stern, 'Water supply in Britain: the development of a public service', Royal Sanitary Inst. J., 1954, 74: 998-1003.

10 Mitchell and Leys, op. cit., note 1 above, p. 269.

"Dickinson, op. cit., note 9 above, p. 7.

12 Royal Commission on the Water Supply of the Metropolis, BPP 1828 IX, pp. 56-58.

13 Dickinson, op. cit., note 9 above, p. 57.

14 P. M. Mathias, The brewing industry in England 1700-1830, Cambridge University Press, 1959, ch. 1; Alan Everitt, 'The English urban inn', in Alan Everitt (editor), Perspectives in English history, London, Macmillan, 1973. William Ibell, milliner, described the ill effect Grand Junction water had on his female employees. Their male colleagues were not affected. Royal Commission 1828, p. 104.

15 Ibid., p. 105.

16 Ibid., pp. 102-103.
} 


\section{Water and the search for public health in London}

The quality of Thames water, despite the turbidity inevitable in major river waters, was probably not particularly bad in the eighteenth century. The city did not stretch very far upstream at this period, fish were still plentiful in the river, and stringent regulations existed prohibiting the discharge of noxious matters into the London sewers. ${ }^{17}$ It was not until after 1815 that, for a variety of reasons, ${ }^{18}$ the condition of the river deteriorated dangerously. Leslie Wood, in his recently published study of the history of the pollution of the Thames, concludes that the condition of the river in the eighteenth century was not very different from its condition today. ${ }^{19}$ Public consciousness of water quality developed only slowly through the eighteenth century. It is perhaps an indication of a spreading refinement of taste that the companies began to build settling reservoirs in order to clarify their water before distribution from 1808; previously, the New River Company had attempted to ensure that weed growth, etc., was removed from its channel, and the other companies had placed screens or perforated pipes across their river intakes (known as "dolphins") to prevent the passage of grosser kinds of rubbish. ${ }^{20}$ There is evidence to suggest, however, that, despite authoritative urgings that clarity also indicated purity in water, ordinary people long preferred to allow taste to decide the source of their water supply. The various city wells were patronized on these grounds, and their supplies were often as turbid as those of the Thames. ${ }^{21}$ The reasons for the slow development of concern with water quality may lie in the gradually deteriorating quality of the Thames through the eighteenth century, and in the increasing refinement of late eighteenth-century taste, but they lie also in the gradual evolution of medical and scientific ideas during this period, and in the emergence, in the wake of the French Revolution, of the popular public voice, or pressure group, as an influence in public affairs.

The use of water, and particularly of spring waters, for medicinal purposes, has a long history. The English watering place can be traced back to Roman times, and a number of springs and wells retained their local renown throughout the Middle Ages and into the sixteenth century. ${ }^{22}$ From the 1560 s, in the period when the first popular medical books began to appear, English physicians wrote of the virtues of such waters, the attributes of particular spas, and the variety of ills that might be alleviated by drinking their waters. ${ }^{23}$ By the later sixteenth century, both Bath and Buxton already enjoyed noble patronage. ${ }^{24}$ The development of secular society after the Restoration of 1660, and rising prosperity among the middle and upper classes, brought the flowering of spa towns, and places such as Bath, Tunbridge Wells, Cheltenham, and Harrogate emerged as medical and recreational centres. Visits to these resorts were made not only in search of remedies for specific ills, but also for more general recuperative purposes. The heavy eating and drinking, and excessive socializing that characterized the lives of the wealthier classes at this period, took their toll of many

\footnotetext{
17 Wood, op. cit., note 5 above, p. 10. The sewers were intended to carry only surface water.

18 See below.

19 Wood, op. cit., note 5 above, p. 19.

20 Dickinson, op. cit., note 9 above, p. 119.

${ }^{21}$ Lucas, op. cit., note 3 above, vol. 1, pp. 139-150.

${ }^{22}$ S. M. Macintyre, 'Towns as health and pleasure resorts', Oxford DPhil. thesis, 1973, p. 2.

${ }^{23}$ Ibid.; see also R. Lennard, Englishmen at rest and play, Oxford University Press, 1931, ch. 1.

24 MacIntyre, op. cit., note 22 above, p. 2.
} 
constitutions. Lord Chesterfield, for example, accepting in 1743 the dedication of a volume entitled The natural method of cureing the diseases of the body, wrote that he intended to return to take the waters of Bath again: "I find my shattered tenement admits of but half repairs and requires them annually". 25

Since the early seventeenth century, when the idea of visiting spas first became popular, English physicians had been curious about the active principles of natural mineral waters, and had begun to develop methods for their analysis. ${ }^{26}$ Medical and popular emphasis on the benefits of spa water, and later in the eighteenth century of sea water, directed attention to water of less refined kinds. As early as 1679, Nehemiah Grew read a paper before the Royal Society on the salts of several waters from the City of London, "extracted, produced before the company, and examined". ${ }^{27}$ The limits of chemical knowledge at this time meant that such investigations were confined to the mineral properties of waters; the possibility of organic substances being present was not considered. The popular medical writers of the early eighteenth century, indeed, made no reference to quality of water. One of the most successful, $\mathrm{Dr}$ George Cheyne of Bath, ${ }^{28}$ although advocating the use of water rather than strong liquor for daily drinking, made no mention of the quality of water to be drunk, probably because it was not yet considered important. ${ }^{29}$ It was said, indeed, that he had long arguments with his friend Beau Nash on the subjects of health and the best cures for diseases. Nash favoured the use of Bath water, while Cheyne took his stand on the eating of cabbages and carrots. ${ }^{30}$

The uncertainties of chemical analysis produced many bitter disputes between rival physicians and rival methods at this period. ${ }^{31}$ Among the most outspoken critics of Bath water and Bath physicians was Charles Lucas, an exiled Irish patriot, who had qualified as a doctor in Paris. ${ }^{32}$ Lucas's attack on the Bath waters was contained in his three-volume Essay on waters, published in 1756. This work is, however, of wider significance, since it appears to be the first attempt at a systematic analysis of various waters and their qualities. Lucas himself implied that the work was entirely original: water, he observed, "the most useful and necessary part of the creation, whether economically, physically, or medicinally considered, has been so far, and so long neglected...". ${ }^{33}$ Although he denied any intention of attacking the Bath waters, his argument was, essentially, that "simple" waters were as beneficial to the health as

${ }^{25}$ J. M. Bulloch, An Aberdeen Falstaff: Dr George Cheyne, Aberdeen University Press, 1930, p. 14.

${ }^{26}$ Noel G. Coley, 'Physicians and the chemical analysis of mineral waters in eighteenth-century England', Med. Hist., 1982, 26: 123-144.

27 John Evelyn, Diary, Oxford University Press, 1959: 17 June 1669.

2s For Cheyne's position among popular health writers see R. R. Trail, 'Sydenham's impact on English medicine', Med. Hist., 1965, 9: 356-364.

${ }^{29} \mathrm{G}$. Cheyne, Essay on health and long life, London, Strahan \& Leake, 1724, pp. 42-43.

${ }^{30}$ Bulloch, op. cit., note 25 above, pp. 16-17. Cheyne, who moved in the best eighteenth-century society, and was accounted very good company, became immensely fat as a result of his indulgence in the pleasures of society. His dietary system was the result of his efforts at self-medication. Although it fell within the Hippocratic tradition, Cheyne claimed that the system was original in its actual recommendations. See $R$. S. Siddall, 'George Cheyne MD: eighteenth century clinician and medical author', Ann. med. Hist., 1942, pp. 99-100.

31 Coley, op. cit., note 26 above, pp. 129, 133.

32 Ibid., pp. 134-135.

${ }^{33}$ Lucas, op. cit., note 3 above, vol. 1, p. 81 . 


\section{Water and the search for public health in London}

"medicinal" ones. Lucas's survey is also valuable as an example of mid-eighteenthcentury medical concern with water. He observed that there existed an almost infinite variety of water, so that it was necessary to distinguish which kinds were most fit "for the principal purposes of life". His criteria illustrate the comparative simplicity of contemporary standards: ${ }^{34}$

Nature early teaches us to distinguish waters by the common test of our sences [sic]: 1. We look upon no water to be pure or simple, that does not upon sight appear, pellucid or clear, and colourless; and the more clear and colourless it is, the better we justly pronounce it. Such water upon standing lets fall no sediment. 2. No water can be thought pure, but such as is perfectly inodorous. 3. No water can be pure, that is not quite insipid; though some insipid waters are far from pure: most terrene or petrifying waters are tasteless. 4. The purest water makes the greatest noise, when poured out of one vessel into another:5. The purest water wets soonest and most, and feels soft to the touch. But, though these be the first trials to be made on water, as the senses differ in most men, we are not to trust solely to them; they only guide us to the proper and conclusive trials.

The proper and conclusive trials were those established by the "rules of chemistry"; in fact, by the long-established method of mineral water examination, which covered first, the physical characteristics of the water; second, chemical tests and tests of the residue after evaporation; third, its observed medicinal effects..$^{35}$ Lucas specifically noted that "no artificer requires so great accuracy in the choice of water" as the chemist, who used it for "elixiviation, solution, precipitation, lotion, or ablution, crystallisation, distillation and numberless other operations". If the water was not pure, the chemist was liable to "endless errors and remediless deceptions" ${ }^{36}$ Lucas's researches convinced him that it was "absurd to imagine" that any water known to man was perfectly pure. Even meteoric or atmospheric waters (dew, rain, snow) were affected by the medium through which they passed, and that of the vessels into which they were received. ${ }^{37}$

Among the waters which Lucas included in his survey were a number of the London waters. London, he considered, was served with water in greater variety and abundance than any city in Europe: "... there is not a considerable street in London which is not furnished with such plenty of water, by way of aqueducts or pipes, from various sources, besides what wells and pumps supply ... but even the upper story of most houses are, or may be, supplied with water ...". Common cocks in the broadest streets watered them in summer, and cleansed them in winter; the abundance of water removed the need for hawkers of water such as could be seen in Paris and other great cities, and, "undoubtedly is one of the principal causes why our capital is the most healthful great city in the world" ${ }^{38}$ He tested the waters of the Thames, the New River, the Hampstead ponds, the large spring in Rathbone Place (from which several streets were supplied), and a number of wells. His results are interesting both as an early example of the practical application of chemical methods, and as an early milestone among London water analyses.

The Thames and New River waters were alike turbid, but attained a similar degree

\footnotetext{
${ }^{34}$ Ibid., pp. 81-82. Samuel Johnson remarked somewhat ironically of this passage, "We are taught to try and select water for the purpose of life". Literary Magazine, 1756, p. 168.

${ }^{35}$ Coley, op. cit., note 26 above, pp. 123-124.

${ }^{36}$ Lucas, op. cit., note 3 above, vol. 1, p. 83.

${ }^{37}$ Ibid., p. 84.

38 Ibid., p. 127.
} 


\section{Anne Hardy}

of clarity when allowed to settle. They yielded sixteen and fourteen grains of solid matter per gallon respectively (the Bath waters, by comparison, yielded an average of sixteen grains per pint ${ }^{39}$ ). This quantity, Lucas observed, was "very inconsiderable" it was not easy to collect rainwater with less, especially near a great city. Although he noted that the turbidity of the Thames must be due to the "foregne mixture it receives about London", Lucas had no medical objection to these waters. They might, with perfect propriety, be used for drinking, bathing, washing, cooking, brewing, and preparing medicines. However, for the exact dilution of solutions for precipitations; for the washing of magisteries; for the dyeing of tenderer colours; for the accurate crystallization of salts, and the like operations, purer waters should be sought by the curious spectator. ${ }^{10}$ The human constitution was not, as yet, counted among the more delicate of nature's mysteries. The results obtained from the other London waters, and Lucas's remarks on the safety and propriety with which they might be drunk by calculous and gouty patients, confirm his lack of particularity about the solid contents of water. The Hampstead ponds yielded four scruples ten grains of matter, which when burnt gave off a smell of burning bricks. The Rathbone Place water gave five scruples per gallon; let stand, it let fall an earthy deposit, and the sides of the glass in which it stood became covered with bubbles. The waters of all the pumps and springs in London and Westminster bore a great resemblance to the Rathbonè Place water: the St Paul's churchyard pump yielded sixty-one grains of solid matter per gallon; the Savoy Pump, fifty-seven grains; Crowder's Well, four scruples; Lamb's Conduit, 20.5 grains of matter of a darker colour than any of the rest. ${ }^{41}$

The period at which the solid contents of drinking-water, its turbidity, and possible organic content, became a matter of medical importance cannot be determined with any precision, but probably began around the time of Lucas's survey. The year 1750 saw the publication of John Pringle's Letter to Dr Mead, which was incorporated two years later into his most famous work, Observations on the diseases of the army. Pringle had been physician-general to the British troops during the campaigns of $1742-3$ in and about Flanders, and subsequently in England. His observations in the field had led him to conclude that camp dysentery was spread by improper sanitary arrangements; he also pointed to putrefying animal matters as a source of disease. ${ }^{42}$ Other work in the middle years of the century began to point to water as a source of disease, rather than as a cure for it. Richard Mead had published, in 1702, the case of a lady who had been troubled with chronic colic, until she took the advice of her physician, and stopped drinking beer brewed with well-water; in 1756, Mead issued a general warning against the practice of brewing beer with well-water. ${ }^{43}$ The observation that goitre in the Alps and Pyrenees was associated with the drinking of water from particular springs made a considerable impact on the medical world.4 By 1769 ,

39 Ibid., vol. 3, p. 311.

40 Ibid., vol. 1, p. 138.

41 Ibid., pp. 139-150.

42 John Simon, English sanitary institutions, 2nd ed., London, John Murray, 1887, p. 115; M. C. Buer, Health, wealth and population in the early days of the Industrial Revolution, London, Routledge \& Kegan Paul, 1926, p. 119.

${ }^{43}$ Richard Mead, Essay on poisons, 1st ed., London, J. Brindley, 1702; 5th ed., 1756, p. 311.

44 Ibid., 5th ed., p. 308; Samuel Sharp, Letters from Italy, London, R. Cave, 1766, p. 297 (Sharp's infor- 


\section{Water and the search for public health in London}

Thomas Percival, better known today as the author of Observations on the state of the population of Manchester (1789), and one of the acknowledged pioneers of the British public health movement, ${ }^{45}$ was writing that water in whatever form had an extensive influence on the health of man. In particular, he noted that the "numberless disorders" of infancy and childhood sprang from "this necessary diluent and vehicle of their food". ${ }^{46}$

Percival warned particularly against the use of "raw" river waters. His observations, however, revealed the limits of comprehension previous to the emergence of the New Chemistry in 1789. All rivers, he wrote, carry with them a great deal of mud, filth, and other impurities, and when they flow near large, populous, and manufacturing towns, become the receptacles of the common sewers, and are impregnated with "an heterogenous mixture of copperas, alum, soap lyes, logwood" and other residual substances. In this state, they are "certainly unfit" for the common purposes of life. Yet if allowed to rest, all the "feculencies" in such water would subside, and it would become "sufficiently pure, grateful, and potable". 47

Percival's interest in the quality of water supplies was a logical part of his wider concern for public health in the urbanenvironment. He was one of the instigators of Manchester's first public health committee in the $1760 \mathrm{~s}^{48}$ and his works form part of a pattern of increasing medical concern at the social conditions and mortality rates prevailing in cities in the latter part of the eighteenth century. Although, from the late seventeenth century, towns throughout England had become increasingly concerned with the provision of public amenities, among which water supplies were a prominent feature, such facilities were not generally extended to the poorer areas. ${ }^{49}$ As is well known, the poorer districts received little civic attention in the early stages of industrialization, and were permitted to grow unregulated by any form of sanitary legislation. ${ }^{30}$ Among the recommendations which the physicians of Liverpool, for example, made to the city corporation in 1788 , were the regulation of industries in the town, especially of the offensive trades (butchering, bone-boiling, cat-gut manufacture, etc.), and the improvement of the pavements and, more particularly, of the common sewers. ${ }^{51}$ Although the public health movement did not reach the national stage until the 1830s, its roots lie very evidently in the interests of such late eighteenth-century figures as Percival and Dr Ferriar at Manchester, Drs Moss and

mation was that the disease was caused by drinking snow-water, and that it was not hereditary); Friedrich Hoffmann of Halle the Younger, Opera, Geneva, 1740-53, vol. 6, pp. 202-203. T. Percival, Observations and experiments on water, London, 1769, pp. 2-3. Goitre is an iodine deficiency disease, affecting the thyroid gland. The absence of iodine in mountain waters which are particularly pure accounts for the geographical distribution of the disease. See also, Bruce A. Gillie, 'Endemic goiter', Sci. Amer., 1971, 224 (6): $92-101$.

45 Buer, op. cit., note 42 above, pp. 122-123.

${ }^{46}$ Percival, op. cit., note 44 above, pp. 2-3.

47 Ibid., pp. 73-74.

48 Buer, op. cit., note 42 above, p. 22.

49 Penelope Corfield, English towns 1700-1800, Oxford University Press, 1982, pp. 120, 157, 177-178.

so $\mathrm{M}$. Beresford, 'The making of a townscape', in C. W. Chalkin and M. A. Havinden (editors), Rural change and urban growth 1500-1800, London, Longmans, 1974. The first English town planning act was passing in 1909: $9 \mathrm{Edw} .7$, ch. 44, part II.

'1 James Currie, Medical reports, 4th ed., London, Cadell, Davies \& Creech, 1805, pp. 372-373. 


\section{Anne Hardy}

Currie at Liverpool, Dr Heysham at Carlisle, Dr Clark of Newcastle, and Dr Lucas of Leeds. $^{32}$

There can be little doubt that the environmental awareness of such men was sharpened in the 1790s by the diffusion of the New Chemistry. Although both organic and analytical chemistry had achieved scientific status through the work of the Swedish chemists C. W. Scheele (1742-1786) and T. O. Bergman (1735-1784), the publication of Antoine Lavoisier's Traité élémentaire de chimie in 1789 opened a new world of systematic endeavour to all disciplines within the scientific spectrum, including agriculture and medicine. ${ }^{53}$ Lavoisier's method was based on quantitative measurement, on analysis and synthesis, on the notion of chemical equation, and on a new chemical nomenclature that effectively banished the obscurities which had hitherto confused chemical explorations. ${ }^{54}$ In England, the advocates of the New Chemistry were forceful propagandists for its general scientific applicability. Richard Reece (1775-1831), later editor of the Monthly Gazette of Health, observed in 1808 that, "at the present time, a new era may be struck by the introduction of the French chemistry into medicine". Since its introduction, "the pursuit of chemistry forming a part of a liberal education, mankind have [sic] become more able judges of professional subjects".ss The distinguished Unitarian chemist, Samuel Parks (1761-1825), similarly stressed not only the need to teach chemistry as an essential part of education, but also its importance to improvement in arts and manufactures. On its relation to medicine, Parks presented a decidedly modern view: ". . . the human body is itself a laboratory, in which, by the various functions of secretion, absorption, \&c., composition and decomposition are perpetually going on: - how, therefore can he [the medical student] expect to understand the animal economy, if he be unacquainted with the effects which certain causes may chemically produce? Every inspiration we take, and every pulse that vibrates within us effects a chemical change upon the animal fluids. ..."'s6

The effect of the New Chemistry as applied to the study of water was certainly to introduce a greater precision in the terms of analysis. Lavoisier's pioneering experiments to determine the composition of organic substances, while in themselves not very successful, were important in showing the correct approach to practical methods of organic elementary analysis. ${ }^{37}$ Although organic chemistry and associated analytical procedures remained a backward area of chemistry until the work of Justus Liebig in the $1830 \mathrm{~s},{ }^{58}$ Lavoisier's work helped to stimulate the concern over the organic content of water supplies which had been rising since John Pringle's illumination of the dangers of putrefying animal wastes. In 1793, James Peacock, architect, observed that medical men readily pointed to the "probable advantages" to the preservation of life and health that would result from the use of soft water, "cleared from

\footnotetext{
s2 Corfield, op. cit., note 49 above, pp. 121-122; M. Flinn (editor), Report on the sanitary condition of the labouring population by Edwin Chadwick, Edinburgh University Press, 1965, introduction, pp. 23-26.

${ }^{33}$ Sir Harold Hartley, Studies in the history of chemistry, Oxford University Press, 1971, pp. 19, 55.

s4 Ibid., p. 55.

ss R. Reece, $A$ dictionary of domestic medicine, London, Longman, 1808, pp. 21-22.

s6 S. Parkes, The chemical catechism, 8th ed., London, 1818, p. 4.

37 Ferenc Szabadvary, History of analytical chemistry, Oxford, Pergamon Press, 1966, p. 287.

s8 Ibid., pp. 288-293.
} 


\section{Water and the search for public health in London}

the earthy, and the living, dead, and putrid, animal and vegetable substances, with which it is always more or less, defiled and vitiated". The majority of mankind, however, drank water no matter how turbid it happened to be, "without the least hesitation". 39 The recognition of the dangers of organic solids in water had not as yet spread very far outside medical circles.

Peacock had, nevertheless, invented a system of water filtration, which would provide clear water for family or community use. Whether he was the first to do so is debatable: although earlier literature mentions distillation, and resting water to allow impurities to subside, there seems to be no actual reference to filtration. Peacock certainly wrote as if his idea were original, but this is not in itself conclusive. His system did, however, possess the features which became established as the basis of this technique. He advocated the use of two types of filtration vessel, one of glass, porcelain, or stoneware for family use, and one of wood, brick, marble, or stone for larger purposes: whole districts, villages, towns, and even cities might be so supplied, at "very easy rates". ${ }^{60}$ These cisterns were to be divided into three parts. The first received the turbid water from a service pipe; the second contained a stratified medium for filtration (gravel of different sizes); the third received the clarified water after its ascent through the filter. Peacock recommended that the contraption be cleaned five or six times a year, more if the water was "uncommonly turbid". ${ }^{61}$

Peacock's scheme was not adopted on any large scale at this time (the Chelsea Company, first of the London water companies to introduce filtered supply, did not do so until 1829), although it is apparent that a moderate interest in purer - or clearer water had been aroused, at least in medical circles. In 1816, for example, the Monthly Gazette of Health carried an advertisement for Handcock and Wilson, of Welbeck Street, Cavendish Square (a highly respectable district), who were selling distilled water to the general public, at a cost of $8 d$. per gallon delivered to any part of London, or $6 d$. per gallon at the distillery. ${ }^{62}$ Similarly, in 1819, Mr James of Knightsbridge was advertising his "cheap machine" for depriving water of "impurities and animalcules" by filtration. The machine cost twelve shillings, and would, it was claimed, last a small family two years. ${ }^{63}$ Such devices did not, it seems, achieve a wide sale. In the evidence taken before the first parliamentary inquiry into the quality of water supplied to London in 1828, the medical gentlemen interviewed were almost the only individuals to state that they made use of domestic filter machines. ${ }^{64}$

Although the importance of clean drinking-water was becoming recognized, perhaps the first systematic attempt to point out the consequences of using impure water, and to convert patients from its use, was that made by William Lambe, discoverer of the dangers of lead in water, in the early years of the nineteenth century. Lambe's attention had first been directed to the injurious effects of drinking-water conveyed by lead pipes in 1797, and as a result of his findings, he extended his

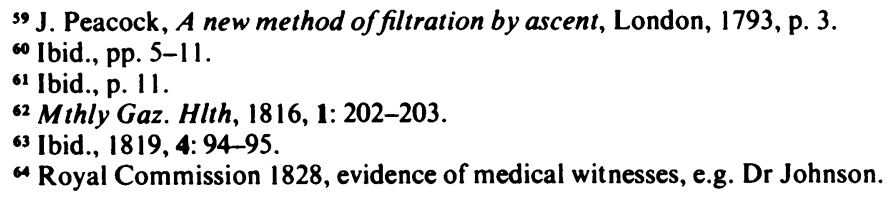




\section{Anne Hardy}

researches to the analysis of other impurities in water. Although he probably did not invent the principle of distilling water at home, as one nineteenth-century source claims, Lambe's work in analysing various drinking-waters was original enough to attract the attention of Humphry Davy. ${ }^{65}$ Lambe was convinced that "putrescent matter" was the "most noxious principle of common water". He had suffered from a variety of digestive and stress disorders all his adult life, and in 1803 began using distilled water as a remedy. In that year, he wrote to his friend Dr Parr: "I beg you will consider my doctrine, that all pump water is poisonous . . .".66

Lambe moved to London in 1805, and established himself in practice there. In 1806, his condition deteriorated to such an extent that he resolved in future to restrict himself to a diet of distilled water and vegetables (the two being of equal importance). His health improved markedly, and he thereafter became an ardent advocate of his own dietary system, including the poet Shelley among his converts. ${ }^{67}$ In his Reports on regimen, in which he detailed his own case history, Lambe recorded his belief that, "The peculiar noxious principle of bad waters is nothing but the corrupted animal and vegetable matters, with which they are impregnated. These matters are therefore poisonous ... actively mischievous ... immediately and directly deleterious; and it is astonishing to consider how greatly the influence of this matter has been overlooked, even by writers who were fully aware of the general importance of the subject."68 Lambe's conviction was not generally shared by the medical world, and a lively controversy arose on the question of how far the presence of foreign matter affected the salubrity of water. Some, like Lambe, insisted that water must be distilled to be pure, and some, in the tradition of Lucas, considered every description of water perfectly healthy. ${ }^{69}$ There was no means of settling this dispute. Turbid water did not immediately and consistently produce recognizable ill effects, while difficulties surrounded the results of analysis: was contamination limited to what was found suspended in water, or were there elements "truely dissolved" in the water that would remain dangerous even after filtration? ${ }^{70}$

These discussions were brought to a head, and the question of the purity of London water supplies in general first brought before the public eye, in March 1827, when a pamphlet entitled The dolphin was distributed to houses in the city of Westminster. ${ }^{\text {1 }}$ An attack on the Grand Junction Water Company, whose intake from the river at Chelsea lay within a few yards of the outflow of the Ranelagh Sewer, this pamphlet is of some significance, for in tone and contents it marks the emergence of the nineteenth-century public health movement, with its appeal to the general public, and its sensationalist approach. The history of the pamphlet's appearance is equally sig-

${ }^{65}$ E. Hare, The life of William Lambe, London, Pitman, 1873, p. 18. I have been unable to trace the work that Hare gives as his source on this point.

66 Ibid., p. 23.

${ }^{67}$ H. Saxe Wyndham, William Lambe MD, London, Vegetarian Society, 1940, pp. 14-15.

68 J. Wright, The dolphin, London, T. Butcher, 1827, p. 24. The British Library copy of Reports on regimen has been mislaid.

${ }_{69} \mathrm{~J}$. A. Paris, $A$ treatise on diet, London, Underwood, 1826, p. 120.

70 Ibid., p. 122.

"For the history of this pamphlet, see W. M. Stern, 'J. Wright; pamphleteer on London water supply', Guildhall Miscellany, 1953, 2: 31-34; D. Lipschutz, 'The water question in London', Bull. Hist. Med., 1968, 42: $510-525$. 


\section{Water and the search for public health in London}

nificant, for it reveals not simply a protest, but a specifically political motive. ${ }^{22}$ The author, discreetly anonymous, was John Wright, editor of Hansard, and a former colleague of William Cobbett. Since the previous December, he had been working with the Radical MP, Sir Francis Burdett, to maximize the public and parliamentary impact of the pamphlet. ${ }^{73}$ A public meeting on the subject was arranged (attended by such figures as Burdett, Lord Salisbury, Lord Jersey, Sir Henry Halford, John Cam Hobhouse, Professor W. T. Brande, and Samuel Rogers), newspaper coverage obtained, and Burdett pressed for a parliamentary inquiry into the quality of the London water supply. ${ }^{74}$ The latter was obtained without difficulty, if with some delay, since, as one contemporary later recalled, "... the whole town was in convulsions under the notion that they should be poisoned with filthy water". ${ }^{75}$

The Royal Commission appointed to inquire into the water supply of the metropolis in 1828 consisted of three persons: P. M. Roget, physician, William Brande, chemist, and Thomas Telford, the distinguished engineer. ${ }^{76}$ The three disciplines which were to be principally concerned with the quality of the capital's water supply throughout the century were already equally involved in this, the first of a series of explorations of the problem. The Commission had three subjects to investigate: the quantity of water supplied to the metropolis; its quality; and the provision of new methods or sources of supply.

The scope of the inquiry was, however, limited to the water provision of the companies: it was, therefore, essentially concerned only with the comfort and welfare of the wealthy classes and industrialists, and not with that of the common people of London, whose sources of water remained scarce and unsatisfactory, as they probably always had been. Evidence was taken over a period of days, from representatives of the water companies, from doctors, employers, fishermen, plumbers, publicans, hospital stewards, and engineers. The Commission concluded that, although the quantity of water supplied to the metropolis was satisfactory, the quality was less so. The Commission's analyst, however, found that Thames water in itself had "considerable purity"; that is, the water was largely polluted by suspended matters rather than by substances dissolved or chemically combined with it. Filtration through a sand-bed would remove a very considerable part, if not the whole, of such matters, and this might be done, "within such limits of expense as no serious objection can be urged [sic]". ${ }^{77}$ The question of alternative sources of supply was referred to a separate inquiry, to be conducted by Telford. ${ }^{78}$

${ }^{72}$ See Stern, op. cit., note 71 above; and Lipschutz, op. cit., note 71 above, pp. 514-515.

73 Ibid.

74 Royal Commission 1828, memoir of Mr Wright, p. 17.

$7 s$ Fraser's Magazine, 1834, 10: 562; Lipschutz, op. cit., note 71 above, p. 518.

76 P. M. Roget (1779-1869), physician to the Northern Dispensary, London, 1809-1827; first Fullerian Professor of Physiology at the Royal Institution, 1833; founder of the Society for the Diffusion of Useful Knowledge; compiler of Roget's Thesaurus, 1852. W. T. Brande (1788-1866), professor of chemistry at the Royal Institution since 1813; FRS, 1809. Thomas Telford (1757-1834), engineer; architect of the Ellesmere Canal, the Caledonian Canal, the Menai Bridge, etc.

"7 Royal Commission 1828, pp. 121-123.

7 Ibid., p. 78. This inquiry finally emerged as the Select Committee on the Supply of Water to the Metropolis, BPP 1834 XV. It was marred by quarrels between the ageing Telford and his assistants, and did not reach any satisfactory conclusion. 


\section{Anne Hardy}

Most of the evidence given before the Commission was impressionistic (even the physicians relied simply on their senses of sight, taste, and smell in judging the company water), and much of it was colourful. Thames fish, for example, were said to climb out of bad water on to pieces of driftwood and bundles of weeds, gasping for air. ${ }^{79}$ The witnesses, in general, agreed that the quality of Thames water had gradually deteriorated in the previous ten or twelve years; that is, since about 1816. The principal causes of this deterioration were suggested as being the increase in industrial effluent, notably from the gas industry, passing into the river; ${ }^{80}$ the steam boats, whose constant passage stirred up the river bed;1 and the greater flow of water through the sewers, which had led to unprecedented pollution of the river: human wastes had formerly been collected by the night-soil men, and removed for manure purposes. ${ }^{82}$ John Wright, in a memoir submitted to the Commission (he was not called as a witness), referred to the "total and entire change" that had taken place in metropolitan municipal drainage regulations in the last few years. Whereas the Corporation of London had formerly prohibited the casting of soil and filth into the river, this was now positively encouraged as a means of disposal. ${ }^{83}$ Other polluting factors noted by the Commission included the recent rapid growth of population in the city and its region, the position of the companies' intake pipes, and the numbers of dead animals and the amount of slaughter-house offal being thrown into the river ${ }^{84}$

Contemporary opinion that a real deterioration occurred in the condition of the Thames after 1816 is confirmed by the most recent study of the river's modern pollution history. ${ }^{85}$ Although the various factors observed by the Royal Commission of 1828 were not unimportant, rapid deterioration in the early nineteenth century was principally due to industrial pollution (especially from the gas industry), the growth of the city, and the introduction of the water-closet combined with the change in drainage policy. The diffusion of the water-closet, indeed, created the conditions which were so greatly to exercise public health reformers for the next hundred years. ${ }^{86}$ The efficient water carriage of human wastes on a large scale became possible with Joseph Bramah's introduction of the improved version of the water-closet in the 1770s. ${ }^{87}$ Between 1778 and 1797 , Bramah supplied over 6,000 water-closets; and by

79 Royal Commission 1828, pp. 121, 123.

${ }^{20}$ The first London gas company was set up in 1812 . By 1815 , there were thirty miles of gas mains laid in the city. The wet lime purification of gas, which was practised from 1806 until the 1860 s, produced an offensive residue ("blue billy"), which the Gas Light and Coke Company discharged directly into the Thames from 1817 onwards through a pipe laid from the Company works in Great Peter Street, Westminster. See T. I. Williams, $A$ history of the British gas industry, Oxford University Press, 1981, p. 15; S. Everard, The history of the Gas Light and Coke Company, London, Ernest Benn, 1949, p. 65.

31 The number of steam vessels registered in the United Kingdom rose from eleven in 1814 to seventyeight in 1820 and 338 in 1828. There were fifty-seven registered in the Port of London in 1829: Accounts and Papers, BPP 1829 XVIII, pp. 191, 198. The number of coasting and foreign steam vessels entering the Port was nil in 1820, but rose to 361 in 1830; in 1820, there were four steam boats carrying passengers within the limits of the Port, but by 1830 there were 20: Accounts and Papers, BPP 1836 XIV, pp. 532, 538-54I.

${ }^{32}$ Royal Commission 1828, p. 62.

33 Ibid., John Wright's memoir, p. 199.

st Ibid., p. 62.

ss Wood, op. cit., note 5 above, see pp. 19-22.

${ }^{86}$ It was not until the Metropolitan Water Board was able to introduce the treatment of the London water supply with chlorine in the early 1920 s that fears of accidental sewage pollution were laid to rest.

$"$ Wood, op. cit., note 5 above, pp. 21-22. 


\section{Water and the search for public health in London}

the 1830s, they were being widely used in London. In 1844, the great builder, Thomas Cubitt, ${ }^{88}$ observed that although the public was not yet ready to accept legislation enforcing the provision of a water-closet in every home, ten water-closets were now being installed in new buildings for every one that had been installed twenty years previously. ${ }^{89}$ Household drains were not permitted direct connexion to the London sewers until 1815, when the prohibition was lifted. By 1828 , estimates of the number of sewers discharging into the Thames at London varied from 139 to $145 .{ }^{90}$ Although it is impossible to say how effective the anti-pollution regulations were up to 1815 , there can be little doubt that there was a substantial increase in sewage pollution of the river after that date, partly because of the removal of restriction, but principally because of the spread of the water-closet. Thomas Cubitt testified that in 1844, very few common privies did not empty themselves into the common sewers. Forty years earlier (that is about 1803), these had drained into cesspools throughout London, but in recent years they had been connected to the sewers, and the river now received nearly all their contents. ${ }^{91}$

The conditions revealed by the 1828 Royal Commission did not stimulate any redressive legislation; and in spite of the acute public interest of 1828 , the question of the London water supply largely disappeared from view until $1850 .{ }^{92}$ The phenomenon need cause no surprise: the history of popular public interest in health matters in Britain follows a consistent pattern of sporadic intense concern, followed by long periods of indifference. Nevertheless, in view of the fears of 1828 , it is remarkable that in the cholera literature of 1832 , a mere four years later, only one anonymous pamphleteer suggested a connexion between the disease and water supply. ${ }^{93}$ The general development of the public health idea during the 1830 s served, however, to redirect medical and sanitary interests towards water, and also to integrate the water question into a wider framework of sanitary concern, linking it to problems of drainage and house construction, domestic habits, poverty, and disease. The early studies of local problems of health and disease by independent doctors were supplemented from the later 1830s by officially sponsored inquiries, of which the first was that into the causes of fever in certain areas of the metropolis undertaken by Drs Kay, Arnott, and Southwood Smith under the aegis of the Poor Law Board in 1838. ${ }^{94}$ Kay and Arnott, in particular, emphasized the importance of adequate water supplies in poor districts for drainage and sewerage purposes, and to allow "sufficiently" the washing of streets, houses, clothing, and persons.95 By 1840, it could be observed that, "The importance of an ample and due supply of water within the reach and means of the humbler

\footnotetext{
88 Thomas Cubitt (1788-1855), besides shaping the character of south-west central London, even as it survives today, took a keen interest in the problems of the city, notably in the areas of sanitary reform and public health. For the career and achievements of this remarkable man, see Hermione Hobhouse, Thomas Cubitt, London, Macmillan, 1971.

" Royal Commission on the State of Large Towns and Populous Districts, BPP 1844 XVIII, q. 181.

90 Royal Commission 1828, pp. 113, 200.

91 Royal Commission 1844, q. 188.

92 With the exception of the abortive select committee of 1834 , this period is characterized by an absence of parliamentary inquiries into water supply.

${ }^{93}$ Lipschutz, op. cit., note 71 above, p. 525. M. Durey, The return of the plague, London, Gill \& Macmillan, 1979, ch. 3.

94 Flinn, op. cit., note 52 above, pp. 30-35.

95 Fourth annual report of the Poor Law Commissioners, BPP 1837-8 XXVIII, pp. 216-217.
} 
classes has been evident to all who have attended to the subject, and appears lamentably deficient in several populous and increasing communities."96 In the 1830s, therefore, water supplies were being seen for the first time on a public canvas, as they affected the poorer classes; a concern that had scarcely been broached in previous debates on the quantity and quality of urban water supplies.

The further investigations of the middle classes into urban conditions of the 1840s helped to place water firmly among those subjects at the heart of any sanitary reform programme. Edwin Chadwick's eyes were opened to the significance of water supplies by the material which he collected for his Sanitary report of 1842 . No previous investigation, he wrote, had made him conceive of the privations which the working classes were subjected to through inadequate supplies of water for washing, cleansing, and sewerage, and of wholesome water supplies for drinking and cooking. ${ }^{97}$ Supplies of water in such areas had to be fetched from wells or stopcocks, and carried in buckets or other vessels. In such vessels it would also be stored, uncovered, in rooms used constantly by the family, exposed to many forms of contamination, and be used and reused for various purposes. Among the examples of such unsatisfactory provision cited by Chadwick was the working man of Bath, whose water for drinking and all other purposes was taken from the river, in spite of its being muddy and frequently foul-smelling from the filth which it carried. ${ }^{98}$ The impact of Chadwick's report has been described elsewhere; 99 its specific role in wakening a consciousness of the general problem of urban water supplies can be seen in, for example, the evidence of Joseph Toynbee, dispensary surgeon, before the Royal Commission on the Health of Towns (1844). Toynbee stated that it was the Sanitary report which had drawn his attention to water quality. He had investigated further on his own account, and his inquiries had convinced him that the quality of water, the mode of its transmission, and the atmosphere in which it was kept influenced the health of the population "to a much more serious extent than has hitherto been imagined" ${ }^{100}$

The scientific evidence of the link between organically contaminated water and ill health continued, however, to be inconclusive. Thomas Clarke, professor of chemistry at Aberdeen, was not prepared to make any statement on this subject to the 1844 Royal Commission. When questioned as to the likely effect on health of the constant use of water containing animal and vegetable impurities, he observed that despite the interest of the subject, little accurate information had been obtained. ${ }^{101} \mathrm{He}$ himself had, however, found animalcules visible to the naked eye in all the London company waters: he had never observed any such creatures in any town's water before (contrary evidence was given on this point by other witnesses). ${ }^{102}$ The continuing limitations of

${ }^{96}$ Select Committee on the Health of Towns, BPP 1840 XI, p. 296.

"Flinn, op. cit., note 52 above, p. 135.

98 Ibid., p. 141-142.

${ }^{99}$ S. E. Finer, The life and times of Sir Edwin Chadwick, London, Methuen, 1952, pp. 230-243. For a good general account of the public health interest and of conditions in early Victorian London see $F$. Sheppard, London 1808-1870: the infernal wen, London, Secker \& Warburg, 1971, ch. 7. There is, however, no indication that Chadwick made any specific connexion between water and disease: clean water was part of the general environmental improvements desirable for health.

100 Royal Commission 1844, q. 5548.

101 Ibid., q. 42.

${ }^{102}$ Ibid., qq. 83, 84. 


\section{Water and the search for public health in London}

science enhanced the value of practical observations such as that made by Southwood Smith on the same occasion: in every district in which fever epidemics were frequent, there was uniformly bad sewerage, bad water supply, bad scavenging, and a consequent accumulation of filth. ${ }^{103}$ Several medical witnesses suggested that the remedy for these problems was a constant supply of piped water to the poor districts as well as the wealthy ones. The 1844 Royal Commission marks the first appearance of this sanitary demand. ${ }^{104}$ Although provision was made in the 1847 Waterworks Clauses Act for the extension of company water supplies on the constant system throughout London, it was another fifty years before this particular sanitary ambition was fulfilled. ${ }^{105}$

The general investigations into urban conditions of the early 1840s were given more precise orientation by the work of the General Board of Health appointed in 1848. Among the subjects which the Board specifically inquired into was the water supply of London, and the interest that this inquiry aroused in the water question resulted in legislation in 1852. ${ }^{106}$ The Metropolis Water Supply Act, 1852, did not follow the recommendation of the General Board of Health to remove the source of London water to Farnham and the Surrey Sands, far from the contaminating influence of the metropolis, because a government inquiry by three chemists into the chemical quality of the London supply had, in 1851, suggested that this development was not, as yet, necessary. ${ }^{107}$ Tidal drainage above London was not yet significant: "The river may reasonably be supposed to possess, in its self-purifying power, the means of recovery from an amount of contaminating injury equal to what is at present exposed to its higher section." 108 The chemists still believed that where organic contamination was concerned "the indefinite dilution of such matters in the vast volume of the well aerated stream is likely to lead to their destruction by oxidation, and to cause their disappearance". ${ }^{109}$ Nevertheless, they were worried about the continuing growth of population and industry in the London area, and the probability of increasing organic and chemical pollution of the river. If the Thames were to continue as any considerable source of water for London, they recommended that the intakes should be removed to a point away from contamination, and entirely above the tidal flow of the river. It was also pointed out that, if the intakes were placed above Teddington Lock, discoloration of drinking-water by the turbid floods of the river Brent would be avoided. ${ }^{110}$

The anti-pollution measures contained in the 1852 Act were largely shaped by the opinion of the chemists. The London water companies were confirmed in their position as the monopoly holders of water distribution in the city, in spite of public pres-

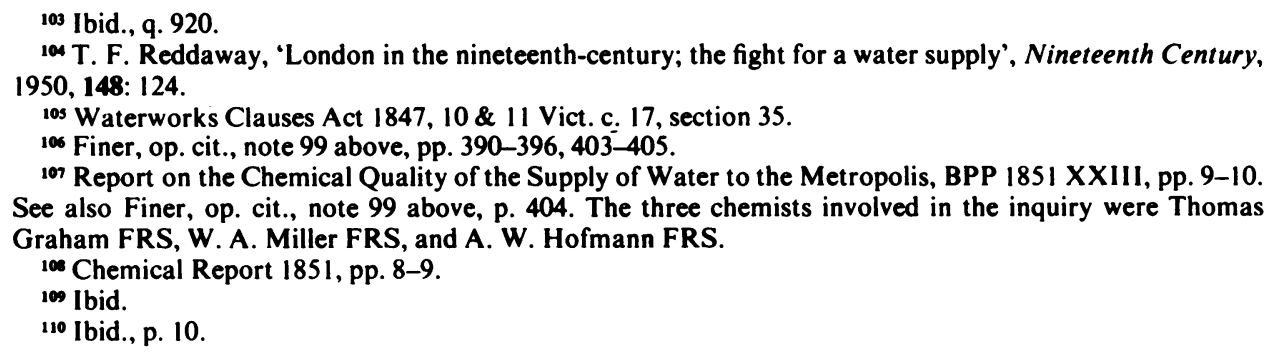

${ }^{104}$ T. F. Reddaway, 'London in the nineteenth-century; the fight for a water supply', Nineteenth Century, 1950, 148: 124. 


\section{Anne Hardy}

sure for their replacement by some form of municipal control. ${ }^{111}$ The companies agreed to remove their Thames intakes to above Teddington Lock, and to submit any proposed changes in the source of supply to the inspection and approval of the Board of Trade. They undertook to cover their reservoir, and to filter their water "effectually" before delivery. ${ }^{112}$ These measures with regard to supply marked the culmination of a process of steady improvement which had begun with the building of settling reservoirs early in the century, and continued with the general introduction of filter beds in the 1830s, and of storage reservoirs in the 1840s. ${ }^{113}$ The 1852 Act was, however, far from solving all the problems associated with the London water supply. The impression given by Reddaway, for example, that London's water supply was on a satisfactory basis thereafter, is misleading. ${ }^{114}$ Both quantity and quality remained concerns central to metropolitan sanitary reformers until the end of the nineteenth century, and although this anxiety can be seen to have been partly the result of still incomplete scientific understanding, there can be little doubt that there remained grounds for disquiet.

The 1850s nevertheless marked a new phase in environmental improvement in London. The Metropolis Local Management Act, 1855, established a new administrative network for the city (civil parishes administered by vestries elected by and from the ratepayers), as well as a higher authority, the Metropolitan Board of Works, with responsibility for certain concerns of the whole capital. ${ }^{115}$ Principal among the projects which it undertook was the main drainage of the city. ${ }^{116}$ At this date, London had nothing resembling a main drainage system, let alone one that bore any relation to environmental hygiene. The early sanitary investigations abound in descriptions of leaking cesspools, uncovered drains, open sewers, stagnant surface waters, and hideous middens. Such sewers as there were drained unashamedly into the river, while the surface wells which still supplied much of the city's domestic water were frequently contaminated by seepage from the various and unregulated drainage arrangements. ${ }^{117}$

111 Public control of the London water supply had been proposed in the first metropolis water bill of 1851 . For public opinion on this issue, see the Select Committee on the Metropolis Water Bill, BPP 1851 XV, evidence of W. Horn, Edward Collinson, B. J. Armstrong, W. Y. Freebody, etc. For a detailed account of the political background to the 1852 Metropolis Water Act, and the subsequent political history of the water question, see A. K. Mukhopadhyay, 'The politics of London water supply 1871-1971', London University PhD thesis, 1972, pp. 11-16 et seq; and idem, 'The politics of London water', London J., 1975, 2: 209-212.

112 Metropolis Water Supply Act 1852, 15 \& 16 Vict. c 84, sections 1-5.

${ }^{113}$ Dickinson, op. cit., note 9 above, pp. 119-121.

114 Reddaway, op. cit., note 104 above, p. 130, remarks that "Water, no longer loaded with decomposed vegetable matter, had become a standard of cleanliness". Although filtration was later discovered to remove some ninety-five per cent of organic pollution from river water, such pollution remained a concern until the twentieth century. There is little doubt that the appearance of London water in the later nineteenth century would often have suggested to modern eyes, as it did to contemporary observers, that the water was far from clean (see note 148 below). No one who had read the later nineteenth-century inquiries into water supply or the writings of the medical officers of health and water analysts, would agree that water, after 1852, was accepted by sanitary reformers, let alone the general public, as a "standard of cleanliness".

115 For the work of these bodies see David Owen, The government of Victorian London, Cambridge, Mass., and London, Belknap Press/Harvard University Press, 1982.

${ }^{116}$ For an excellent account of this work see ibid., ch. 3. See also, C. B. Chapman, 'The year of the great stink', Pharos, July 1972 pp. 90-103.

${ }^{111}$ Also by drainage from graveyards. This problem continued as long as the wells remained. Medical Officer's Report, St George-the-Martyr, 1892, p. 17. 


\section{Water and the search for public health in London}

The 1855 Act admitted that an official system of main drainage for the city was vital, but it was not until the river had contributed its own evidence of serious pollution in 1858 that such a scheme was implemented. Begun in 1859, the main drainage system was largely completed by 1865 , with outlets into the river at Barking Creek and Crossness, below London. Yet although London's pollution of the Thames within its boundaries was effectively curtailed from the mid-1860s, the pollution of the river above London became an increasing concern. The engineering triumph of Joseph Bazalgette, architect of the system, was not in itself sufficient to solve the whole problem of Thames pollution, since agricultural effluent, and that of cities such as Oxford and Reading, which lay above London on the river, continued to flow into it. In 1865, a Royal Commission began to investigate the subject of river pollution throughout the country, and the final report of this body in 1874 was followed by legislation in 1876.

The conclusions of the Royal Commission on Rivers Pollution (once again conducted by chemists) ${ }^{118}$ illustrate the development of chemical thought since the inquiry of 1851 . By 1874 , the sewage contamination of river water was no longer acceptable on the grounds that the movement of the river constituted a self-purifying process. ${ }^{119}$ As late as 1869 , this self-purification process had been widely accepted, ${ }^{120}$ but the Commissioners of 1874 presented chemical proofs to the contrary. ${ }^{121}$ Further, they adduced recent medical experiments to substantiate their argument. They remarked that much physiological and chemical research had shown that several at least of the epidemic diseases were spread by means of living spores or germs. Although this view was barely established on a scientific basis, the experiments made by J.-B. A. Chauveau on the constitution of the infective matter of smallpox, sheeppox, and glanders were the "furthest advance towards the non-theoretical explanation" of these phenomena yet made. ${ }^{122}$ Diseases such as smallpox, diphtheria, measles, scarlet fever, and typhus were known to be transmissible between the healthy and the diseased without personal communication; cholera and typhoid were known to be transmissible through bowel discharges. ${ }^{123}$ The commissioners concluded in uncompromising terms. As a result of their inquiries into polluted water in England, they found that "it is a widely spread custom, both in towns and villages, to drink either the water of rivers into which the excrements of man are discharged, or the water from shallow wells which are largely fed by soakage from middens, sewers or cesspools. Thus vast multitudes of the population are daily exposed to the risk of infection from typhoidal discharges, and periodically to that from cholera

\footnotetext{
118 The original commissioners were Robert Rawlinson (1810-1898), civil engineer, sanitary commissioner during the Crimean War; John Thornhill Harrison, and John Thomas Way. This first commission was dissolved in 1868, and replaced by Sir William Dennison, major-general; Edward Frankland (see note 175 below); and John Chalmers Morton (1821-1888), farming expert, editor of the Agricultural Gazette 1844-1888.

119 Royal Commission on Rivers Pollution, BPP 1874 XXXIII, pp. 464-470.

120 Ibid., p. 464; see also Royal Commission on Water Supply, part 1, 1869 BPP 1868-69 XXXIII, p. ixxix.

121 Royal Commission 1874, pp. 464-470.

122 Ibid., p. 470; for Chauveau's experiments, see Lise Wilkinson, 'Smallpox and the evolution of ideas on acute (viral) infections', Med. Hist., 1979, 23: 1-28, see pp. 17-19.

${ }^{123}$ Royal Commission 1874, p. 471.
} 
dejections."124 Within two years, the Rivers Pollution Prevention Act forbade the deposit in any circumstances, or on any grounds, of the solid refuse of any manufactory, manufacturing process or quarry, or any rubbish, cinders, putrid solid matter or any other waste, including sewage matters, into any river. ${ }^{125}$

The evidence presented to the various parliamentary inquiries into water supply over the years reveals the slow and stumbling process of discovery that lay behind the steady accumulation of legislation on sanitary subjects. The idea of a direct connexion between water and disease, although present in the early nineteenth century, was neither popular nor prominent among the varied theories of disease causation that existed at the time. Although John Snow's first essay on the water-borne nature of cholera appeared in 1849,126 it was not until he was able to demonstrate the working of his theory in 1854 that the link between cholera and water was accepted. As we have seen, it was possible for the chemist Thomas Clarke to claim, in 1844, that no accurate information had been obtained on the connexion between ill health and water: in 1851, his fellow-chemists before the Royal Commission on the metropolis water bill were stoutly maintaining, on the authority of Justus Liebig, the greatest contemporary organic chemist, that the presence of "animalcules" in water was not harmful. ${ }^{127}$ It was the opinion of "every chemist who had considered the subject" that in wellaerated water the presence of oxygen destroyed all putrescent effluvia. ${ }^{128}$ Alfred Taylor, one of the foremost contemporary authorities on poisons, specifically denied the connexion between cholera and water. He pointed out that Guy's Hospital, which did not filter the water which it received, already filtered, from the Southwark and Vauxhall Company, had in 1849 only four cholera cases among 3,772 patients admitted. In Rome, which was supposed to have the best water supply in the world, cholera had been proportionately more severe than in either London or Paris. "We cannot in any part of the world connect the ravages of cholera with the quality of the water."129

The connexion between cholera and water supply was, however, dramatically confirmed in London during the epidemic of 1854. In South London, where two com-

124 Ibid. Although London's main drainage system was completed between 1858 and 1875, with outlets at Crossness and Barking Creek below the city, sewage discharge and flood waters continued a concern. See Royal Commission on Sewage Discharge, BPP 1884 XLI, Historical Note.

${ }_{125}$ Rivers Pollution Prevention Act 1876, 39 \& 40 Vict. c 75, section 2. Even so, deliberate and accidental pollution of the rivers continued. The Staines local board, for example, was prosecuted on four different occasions in 1881-84 for permitting house drainage into the Thames. Lancet, 1888, ii: p. 922. The Local Government Board accepted applications for controlled discharge of polluted waters into rivers where drainage works, etc., made this necessary. (E.g., Annual Report of the LGB, BPP 18.) See also, Owen, op. cit., note 115 above, chapter 3; and A. S. Wohl, Endangered lives: public health in Victorian Britain, London, Dent, 1983, ch. 9.

126 For the development of Snow's theory and the reaction of the medical community, see Margaret Pelling, Cholera, fever and English medicine, Oxford University Press, 1978, ch. 6.

127 Select Committee on the Metropolis Water Bill, BPP 1851 XV, qq. 3854 (Professor Brande), 12200, 12209 (Professor Taylor). Taylor quoted the following passage from Liebig's Letters on chemistry (3rd English ed. published in 1851), in support of his argument: "where you have oxygen evolved from water, or oxygen free in water, you have a condition incompatible with the existence of putrefying or decaying animal matter". J. T. Cooper was more reserved in his opinion that unfiltered water was not dangerous: he had himself never suffered injury from drinking Lambeth Company water, and thought that filtered Thames water was “unexceptionable". Ibid., qq. 9893-9899.

128 Select Committee 1851, q. 12152.

129 Ibid., q. 2230. 


\section{Water and the search for public health in London}

panies, the Lambeth and the Southwark and Vauxhall, served an overlapping area, where many streets contained houses supplied by both, it was found that the cholera pattern coincided most markedly with the source of water supply. The disease affected houses served by the Southwark Company, but not those served by the Lambeth. ${ }^{130}$ John Snow's views on the dissemination of cholera were vindicated, and the connexion between water supply and the disease firmly established. Thus when, during the last English cholera epidemic in $1866,{ }^{131}$ London cholera showed a marked preference for the East End of the city, the implications were quickly clear to contemporaries. Within three days of the concentration of the outbreak becoming clear, John Simon (then Medical Officer to the Privy Council) had issued a warning to the East London Water Company that the water supply of these districts was suspected to be at fault. It was subsequently shown that the East London Company had illegally distributed water from an uncovered reservoir, which was contaminated by infected soakage from the River Lea. ${ }^{132}$

Although in respect of other diseases the likelihood of a causal connexion with water continued to be treated with reservations, ${ }^{133}$ Snow's work, and the events of 1854 and 1866, provided sanitarians and the medical profession with a firm basis from which to publicize the association between polluted water and disease. The lessons of 1854 and 1866 were indeed reflected in legislation within a few years. The 1871 Metropolis Water Act, although not in itself a very satisfactory measure, ${ }^{134}$ secured the appointment of a Metropolitan Water Examiner, and an Auditor, whose salaries were to be paid by the companies, but who were to be responsible to the Board of Trade. ${ }^{135}$ The Act also established the right of the metropolitan authority (the Metropolitan Board of Works to 1889, thereafter the London County Council) to require the provision of constant supply in districts where this was thought necessary. The Act thus established that the operation of the companies was subject, in the public interest, to parliamentary supervision.

The companies remained private commercial organizations, however, and no attempt was yet made to impose any uniform standard on their operations. They continued to pursue different policies and standards in their arrangements. When the Metropolitan Water Examiner surveyed the situation in $1888,{ }^{136}$ he found much variation in detail, but a broad uniformity in company practice. At this time, 49.56 per cent

\footnotetext{
${ }^{130}$ General Board of Health Inquiry in Water Supply, BPP 1850 XXII.

131 Although this was the last epidemic in England, importations of the disease did occur during the later pandemics of the nineteenth century, notably in 1872 and 1893-4. The virtual absence of cholera from England after 1867 was probably not related to improvement in water supplies but rather to the efficiency of the port sanitary authorities established in 1872. See Port and Riparian Sanitary Survey, BPP 1895 LII.

${ }^{132}$ Ninth annual report, Medical Officer to the Privy Council, BPP 1867 xxxvii, appendix 7, especially pp. 296, 310-311. But see W. Luckin, 'Cholera in London - the final catastrophe', Med. Hist., 1977, 21 : $32-42$.

${ }^{133}$ Pelling, op. cit., note 126 above, p. 293. William Budd proved the convection of typhoid by water in 1847 , the first person to do so. See W. Goodall, William Budd, Bristol, 1936, pp. 100, 102. Budd published his work as 'On intestinal fevers', Lancet, 1860, i: 187, 239. The medical profession nevertheless remained divided, many continuing to believe in the spontaneous generation of the disease by dirt, bad air, etc. See David Davis, Typhoid in Bristol, 1879, p. 3; Luckin, op. cit., note 132 above.

134 Mukhopadhyay (1972), op. cit., note 111 above, p. 41.

135 Metropolis Water Act 1871, 34 \& 35 Vict. c 113, sections 11, 12.

${ }^{136}$ F. Bolton and P. A. Scratchley, The London water supply, 2nd ed., London, 1888 (Ist ed., 1884). Bolton had died in 1887 , and this edition was completed for the press by Scratchley.
} 


\section{Anne Hardy}

of London's water was drawn from the Thames, 37.48 per cent from the Lea, and 12.46 per cent from springs and wells (in 1866, the proportions had been 49 per cent, 44 per cent, and 7 per cent respectively), and two companies, the East London and the Southwark and Vauxhall, were actively extending the number of their deep wells. ${ }^{137}$ Bolton admitted that the waters of the Thames and Lea were frequently very turbid and difficult to deal with in the winter months: the filtration processes to which the water was subjected before release were crucial in bringing it to an acceptable standard for domestic use. Bolton stated that the filtration rate should not exceed $2 \frac{1}{2}$ gallons per square foot of filter bed per hour: most of the companies had a rate well below this maximum, and in 1888 the figures were practically the same as in $1884 .{ }^{138}$

TABLE I: AVERAGE FILTRATION RATE OF LONDON WATER COMPANIES, 1888

\begin{tabular}{ll} 
Company & Rate per sq. ft. per hr. \\
New River & $1 \frac{3}{3}$ gallons \\
East London & $1 \frac{1}{3}$ \\
Southwark & $1 \frac{1}{4}$ \\
W. Middlesex & $1 \frac{3}{10}$ \\
Grand Junction & $1 \frac{1}{2}$ \\
Lambeth & $2 \frac{1}{10}$ \\
Chelsea & $1 \frac{3}{4}$ \\
\hline rce Bolton, op cit. footnote 136, p. 29
\end{tabular}

Source: Bolton, op. cit., footnote 136, p. 29.

The filtration processes employed by the seven companies were only broadly uniform. Water was pumped from the river into subsiding reservoirs from where it flowed into brick- or concrete-lined filter basins containing layers of sand and fine or coarse gravel in descending order. In all cases, the water was made to pass vertically downwards; was collected by pipe or brick drains laid on the floor of the filtering basin, and led by conduits into the pure water basin and the well of the distributive pumping-engine. ${ }^{139}$ The thickness of the filtering materials used by the different companies (as well as the size and construction of the reservoirs, basins, etc.) varied greatly, from the eight feet of the Chelsea Company to the two feet nine inches of the Grand Junction. The thickness of the upper sand layer (the most effective) varied from two feet to four feet six inches, and the materials used also varied. The Chelsea Company's layers consisted of coarse and fine sand, shells, and gravel; the West Middlesex used Harwich sand and gravel in two sizes; the Southwark and Vauxhall at their Hampton station used boulders, coarse and fine gravel, hoggin, and sand. ${ }^{140}$ Although the different methods of the various companies may have resulted in greater or less efficient filtration, Bolton made no observations to this effect. His only critical comments, indeed, were directed at the consumer. Water companies were, he remarked, frequently blamed for delivery of unpotable water: "... when if the true delinquent

${ }^{137}$ Ibid., p. 20. In 1888, there were twenty-five deep wells sunk in the chalk about London, fifteen north of the Thames, and ten to the south; ibid., p. 21.

138 Ibid., p. 29.

139 For details of the companies' pumping machinery, see Dickinson, op. cit., note 9 above; also R. Sisley, The London water supply, London, 1899.

140 Bolton, op. cit., note 136 above, pp. $21,135,106,93$. Hoggin is screened or sifted gravel (OED). 


\section{Water and the search for public health in London}

were sought it would be found to be the water consumer himself, whose lack of attention to his cistern and filters created the evils of which he complains". ${ }^{141}$

The filtration standards established by the later nineteenth century remained acceptable thereafter. Yet although practical routes to clean water existed in a great degree by the 1880 s, numerous local problems combined with scientific uncertainty meant that water quality, as well as the quantity of supply, still featured largely among sanitary concerns. Detail of the everyday problems and uncertainties of domestic water supply comes from observers who were intimately involved in the sanitary concerns of the capital, for the institution of local public health services in London in 1856 provided a further element in the search for acceptable water supplies for the city. The London medical officers of health each served a parish. The size of these parishes varied, from Hampstead, with a population of 11,986 in 2,252 acres in 1851 , to Whitechapel where 79,759 persons were crammed on to 406 acres, of which twenty-three were water. The medical officers were the first group of professional men to be employed to investigate and improve social and environmental conditions with a view to lowering death rates and diminishing the toll of preventable disease in the city. Following the pattern set by John Simon in his pioneering work for the City of London, ${ }^{142}$ the medical officers of health were largely concerned with drainage and water supplies. Through their annual reports, ${ }^{143}$ it is possible to obtain a more popular view of contemporary attitudes towards the provision and quality of water. Much of the background is, of course, clear from the parliamentary investigations of the first half of the century. There is no doubt, for example, that the poorer areas of London were inadequately supplied with water by the companies: such supply as there was was intermittent (two or three times a week) and usually from a common cock - a device which meant queues at times when the supply was on, and the necessity of some means of storing water in the home. Too frequently, this was an uncovered bucket or barrel exposed to contamination from all household sources, used and re-used for a multiplicity of purposes. This receptacle was often stationed next to the privy, and thus exposed to pollution from the noxious gases which crept from this insanitary apartment. ${ }^{144}$ Until 1870, water was never supplied on Sundays. ${ }^{145}$

The limited supplies of water available in the poor districts, and the intermittence of supply even in wealthier areas until after 1870 , meant a great reliance on public and private wells. These were usually shallow surface wells, whose supply was derived from the drainings of cesspools, slaughter-houses, and graveyards. Their walls were frequently in a ruinous condition, and were, so Dr Henry Bateson observed, covered with a "ropy, slimy layer of substance, offensive to smell and touch". The water from these wells was, nevertheless, considered by local people to be cool, pure, and

141 Ibid., p. 13.

142 For John Simon's work in the City of London, see R. Lambert, Sir John Simon and English social administration, London, MacKibbon \& Kee, 1962, part II (pp. 99-220); and John Simon, Public health reports, 2 vols., London, Sanitary Institute, 1887.

${ }^{143}$ A collection of the London medical officers' reports is to be found in the Library of the Greater London Council. All such reports referred to here, including those of the MOH of the London County Council, are cited by permission of the Council.

144 Camberwell Vestry Minutes, Medical Officer's report on water, 4 June 1856.

145 This was achieved by a private member's bill. See Hansard, vol. 200, 1870, col. 1372. 


\section{Anne Hardy}

delicious. ${ }^{146}$ Such well-waters were popular. They were valued for their brightness and flavour, despite the repeated warnings of medical officers. ${ }^{147}$ The removal of these "slaughter-wells", as they were called, occurred steadily in the years after 1856, and was popularly regarded as a wrong done to the poor. ${ }^{148}$ In 1875, Dr Dudfield of Kensington noted the "remarkable tenacity" with which the old inhabitants of the parish clung to their surface wells, none of which was safe. The process of abolition was a slow one. In St George-the-Martyr, there were still eleven surface pump wells in 1892 (samples submitted to the public analyst showed them all to be highly charged with sewage and other organic matters); while an unspecified number of surface wells remained in Camberwell in the 1890s. ${ }^{149}$

Although patterns of water-drinking in nineteenth-century urban society are impossible to reconstruct, there is no doubt that supplies of water were essential to the domestic lives of even the very poor and the very rich. Water was used in washing, cooking, and beverages; the spread of the temperance movement from the $1860 \mathrm{~s}$ must have increased the demand for drinking-water. ${ }^{150}$ Water was also used to make tea - that great British consolation, a luxury which even the very poor deemed essential to everyday life. ${ }^{151}$ At every level of society, water was used as a mixer for other drinks: the rich drank eau sucrée and lemonade, the poor diluted their ginger beer and gin with it. ${ }^{152}$ Water shortages caused consumer distress. Although it has been claimed that the 1852 Water Act largely did away with the daily difficulties experienced by the poor in obtaining water, ${ }^{153}$ there is plenty of evidence that water long remained a problem in poor areas. In the hot summer of 1858 , for example, the people in the most densely populated parts of the very poor parish of St George-the-Martyr were to be seen on Sundays going in all directions with saucepans and other utensils in search of water. ${ }^{154}$ At the other end of the social scale, the middle classes were capable of taking the law into their own hands to obtain supplies when necessary. In January 1866, a number of gentlemen in Camberwell were driven to rebel when the local water company failed to provide a supply on a Saturday, Sunday being, as the narrator recorded, a "dies non" to water companies. On the Sunday morning, they arrived at the local turncock's home, threatening to sue the Company and the turncock for failing to supply water, and forced the latter to "unlock the barriers that confined the should-be crystal stream". They thus brought "cleanliness and comfort" to more than 100 homes. ${ }^{155}$

\footnotetext{
146 Medical Officer's annual report, St George-the-Martyr, 1871-2, p. 4.

${ }^{147}$ Camberwell Vestry Minutes, 4 June 1856; Medical Officer's annual report, St Martin-in-the-Fields, 1856, p. 4.

146 Medical Officer's annual report, St George-the-Martyr, 1871-2, p. 4.

149 Medical Officer's annual report, Kensington, 1875, p. 30; Medical Officer's annual report, St Georgethe-Martyr, 1892, p. 26; Camberwell Sewers and Sanitary committee minutes, 22 July 1890.

1so See Brian Harrison, Drink and the Victorians, London, Faber, 1971, chapter 14.

151 Tea consumption in Britain rose from $1.6 \mathrm{lbs}$ per head per annum in the decade 1841-50 to $5.7 \mathrm{lbs}$ in 1891-1900. Although the very poor purchased only minute quantities for use as a condiment rather than as a distinct drink, tea was nevertheless a standard item in their diet. John Burnett, Plenty and want, Edinburgh, Thomas Nelson, 1966, p. 98; Maud Pember Reeves, Round about a pound a week, London, Virago reprints, 1979, p. 103, chs IX, X.

${ }^{152}$ Lancet, 1855, ii: p. 57.

${ }^{153}$ Reddaway, op. cit., note 104 above, p. 130.

154 Medical Officer's second quarterly report, St George-the-Martyr, 1856, p. 3.

195 South London Press, 20 January 1866.
} 


\section{Water and the search for public health in London}

Although the problem of the Sunday supply was solved in $1870,{ }^{156}$ there can be little doubt that public insistence on a constant supply of water, as well as public fastidiousness about water quality, lagged considerably behind the demands that the medical profession and sanitary reformers had formulated on the public's behalf. This is not surprising, in view of the ancient habituation to irregular supplies of water, the relatively recent realization by the medical profession of the dangers of impure water, and the fact that impure waters had been used for so long with so little apparent evil effect. The lurid descriptions which the more radical medical press found it necessary to employ for propaganda purposes reflect the extent of the educational difficulty. In 1855, for example, the Lancet remarked savagely on the universal custom of using "... a diluent into whose chief reservoirs the sewage and excremental matter of the surrounding inhabitants were hourly being poured."157 In the late 1880s, Sir John Simon complained that the domestic water supplies of London bore all the appearance of "third class ditch-water", while Frederic Harrison in 1894 warned that a single epidemic might make the water of London "as deadly as the climate of Vera Cruz". ${ }^{158}$ In spite of such forebodings, progress was noted on this front from time to time. In 1872, the Lancet recorded that householders were at last beginning to follow the physicians' demand for pure water; in 1883, the South London Press noted a public awakening of interest in the water question. ${ }^{159}$

Nevertheless, standards remained low by modern criteria. The increasing involvement of middle-class reformers in improving the habits and manners of the poor did not necessarily entail a consequent application of middle-class standards or facilities. The determination to maintain class differentials could be too great. Octavia Hill, for example, who managed tenement houses for the poorer classes with the intention of impressing higher domestic standards, provided only cold water to her houses, piped to a communal tap on each floor. Tenants who wanted water to hand in their homes would still have to resort to a receptacle system. ${ }^{160}$ Yet even the Hill system was an improvement on the older, unimproved types of tenement housing. In these, there was frequently only a single source of supply to serve many storeys, and such conditions remained the cause of much unhealthiness and inconvenience until late in the century. ${ }^{161}$ Until the 1890 s, an unknown number of privately owned properties were probably without a proper domestic water supply at all, but remained dependent on

156 See note 135 above.

157 Lancet, 1855, ii: p. 57.

158 Simon, op. cit., note 42 above, p. 467; Frederic Harrison, The meaning of history, London, 1894, p. 437. Harrison (1831-1923) was a barrister, president of the London Positivist Community, 1880-1905; founder of the Positivist Review, 1893; and one of the first aldermen of the London County Council.

159 Lancet, 1872, i: 369; South London Press, 31 March 1883.

${ }^{160}$ Royal Commission on the Housing of the Working Classes, BPP 1884-5, XXX, q. 8852. Octavia Hill stated: "Primarily, I should not carry water and drains all over the place; I think that ridiculous. If you have water on every floor that is quite sufficient for working people. It is no hardship to have to carry a pail of water along a flat surface." Although she also stated that in most blocks of workmen's dwellings water was laid on to every tenement, new blocks were still being built at this time without individual water facilities. See The diary of Beatrice Webb, edited by N. and J. MacKenzie, London, Virago, 1982, vol. 1, p. 127. For Octavia Hill's work, see A. S. Wohl, The eternal slum, London, Edward Arnold, 1977, chapter 7.

161 Royal Commission 1884-5, Report, pp. 12, 14-15. 


\section{Anne Hardy}

surface wells. ${ }^{162}$ Before 1891 , the local authorities had no power to compel house owners to supply water for domestic purposes, unless supplying wells were found to be unfit for use; they could only compel the provision of a supply for drainage purposes, that is, for the flushing of water-closets. ${ }^{163}$ Camberwell Vestry, for example, engaged on a long struggle with one Mr Carr in such a case between 1864 and 1867. Carr refused to lay on water to twenty-one houses owned by him, and instead deepened the wells which served them, though only after the Vestry had threatened to undertake the work and charge him the cost. Two years later, there were complaints that the houses were without both water and drains. The medical officer, Dr Bristowe, found that the well-water supply was impure: he was thus able to order the closure of the wells, and the laying-on of company water. Over a period of four months, Carr still refused to provide a supply, and was last heard of, when the Vestry finally took the matter into its own hands, as obstructing the contractor who came at the Vestry's bidding to connect the houses to the main. ${ }^{164}$

The detail of water supply systems also caused problems. Building standards and regulations were still very much in an experimental stage, ${ }^{165}$ and the great nineteenthcentury English moral struggle over the right of the community to regulate the behaviour of the individual for his own and others' good was still not fully resolved. ${ }^{166}$ As a result, local sanitary officers generally did not have powers to enforce sanitary standards which, by the simplest criteria of common sense, they knew to be correct. It was a common practice, for example, for London houses to be furnished with one water-cistern only, for both drinking-water and the flushing of the closet. In poor districts, the water-butt was often kept close by the closet, and was frequently connected to it by a pipe which directed the overflow of the former into the latter. As water flowed for only one or two hours a day, or every other day, whenever the pipe was empty the effluvia from the closet passed along it and into the water-butt, contaminating the water stored there. ${ }^{167}$ Although the ability of water to absorb gases had been known since the eighteenth century, and although contaminated water was recognized by the legislature as an evil, the medical officers had no powers to enforce the provision of distinct supplies for flushing and drinking. ${ }^{168}$ Further problems concerned the cisterns in which piped water was stored, as Bolton suggested. Even where these were adequately protected from household contamination, the seasonal turbidity

16242.75 per cent of houses in London were without a constant water supply in March 1891. Some part of these would have been supplied on an intermittent basis, but local evidence (see note 149 above) suggests that many were still without any form of piped water.

${ }_{103}$ Medical Officer's annual report, Camberwell, 1883-4, pp. 169-170. Under the Public Health (London) Act 1891, (54 \& 55 Vict. c. 76, section 48), an occupied house without a "proper and sufficient" water supply was deemed unfit for human habitation; but powers were given to the local authority only in respect of new or rebuilt housing.

14 Camberwell Sewers and Sanitary Committee Minutes, 24 May 1864, 10 April 1866, 21 October 1866, 12 December 1866, I January 1867, 12 February 1867, 26 March 1867, 14 May 1867.

165 Wohl, op. cit., note 160 above, ch. 4.

16 Oliver MacDonagh, Early Victorian government 1830-1870, London, Weidenfeld \& Nicolson, 1977, chapter 1, pp. 8-21. It was only with the social reforms of the Liberal government of 1906-1914 that the collective principle was practically accepted. R. C. Birch, The shaping of the welfare state, London, Longman, 1974, pp. 22-35.

167 Camberwell Vestry Minutes, 4 June 1856.

16 Medical Officer's annual report, Camberwell, 1883-4, p. 170. 


\section{Water and the search for public health in London}

of the company water supplies meant that muddy deposits usually accumulated in them as water rested there before use. In Paddington, Dr Hardwick recorded that water-cisterns were objectionable in the houses of both rich and poor, while in Kensington the cleaning of cisterns was still a problem in the late $1890 \mathrm{~s} .{ }^{169}$

The complexity of the London leasehold system added to the problems which local authorities faced in trying to safeguard domestic water supplies. In most of the working-class and poor areas of the city, a multiplicity of small property-owners leased houses to one or more tenants. The owner remained responsible for rates and dues on the house, because many such tenancies were very short-term. It not infrequently occurred that the owner of one or more houses failed to pay his water rates, often because previous tenants had absconded without paying the rent. In these circumstances, the water companies would exercise their disciplinary rights, and cut off the water supply to the properties concerned until the rates had been paid. The people thus deprived of water were not, in fact, those from whom payment was owing. Houses were sometimes left for weeks without water and, what infuriated the medical officers, the company would inform the local authority of their proceedings, that the medical officers might take legal measures to have the water supply restored. ${ }^{170}$ The companies' powers to cut off supply for non-payment of rates were limited in 1887 , but not removed altogether, and remained a source of vestry grievance until the end of the century. ${ }^{171}$

The medical officers reported regularly on the quality of water supplied by the companies which served their districts. Some, such as Dr Bristowe of Camberwell and Dr Rendle of St George-the-Martyr, began their own water analyses soon after they were appointed; others relied on external opinion. From the 1860 s, monthly water reports were being performed for both the Registrar-General and the Society of Medical Officers of Health. ${ }^{172}$ The appointment of Francis Bolton, a soldier and electrician, as the first Metropolitan Water Examiner in 1871, was somewhat controversial, and aroused bad feeling among those chemists and doctors who had been engaged in the study of water analyses for many years: Dr Frankland, for example, who had bet making the reports to the Registrar-General since 1864, referred to Bolton scathingly as a "mere inspector of filter beds". ${ }^{173}$ Bolton nevertheless proceeded to make his mark, and before his death in 1887 became a recognized authority on the subject of London water. ${ }^{174}$ By 1881 , there were four different sets of water analyses available to interested parties, one official and three quasi-official. The latter were provided by Frankland for the Registrar-General, by Professors Wanklyn and Cooper for the Local Government Board (for a period of five years only), and by Messrs Crookes, Odling, and Tidy for the water companies. ${ }^{175}$ The results were rather confusing for

\footnotetext{
169 Medical Officer's annual report, Paddington, 1871-2, p. 37; Medical Officer's annual report, Kensington, 1897, pp. 167-170.

170 Medical Officer's annual report, Camberwell, 1883-4, pp. 170-171.

171 Medical Officer's annual report, Kensington, 1897, p. 171.

172 Medical Officer's annual report, Camberwell, 1868-9, pp. 38-39.

173 Medical Officer's annual report, Newington, 1871-2, p. 25.

${ }^{174}$ His reputation was established with the publication in 1884 of his book, The London water supply, London, William Clowes for the International Health Exhibition.

${ }^{17 s}$ Sir Edward Frankland (1825-1899), Professor of Chemistry at, successively, the Royal Chemical
} 


\section{Anne Hardy}

comparative purposes, however, since they were given in three different ways, i.e., the amount of organic contamination was given per 100,000 , or per $1,000,000$ or per 70,000 parts water, and different tabular divisions were used. ${ }^{176}$ The analyses were also made at varying intervals, by the month or daily. It may be worth noting that at least one medical officer, William Iliff of Newington, considered that the single monthly examination made by Frankland was insufficient and unfair to the companies, while the daily reports of the company-employed analysts were more satisfactory. ${ }^{177}$

The proliferation of water analyses was accompanied by some divergence of analytical techniques, as well as their steady development in line with the discoveries of the new bacteriology. Wanklyn, for example, disclosed his ammonia process of water analysis in 1867, and stood by it in spite of much controversy concerning its value, until his death in 1906.178 Shortly after his technique had been published, Pasteur revolutionized the concept of water contamination by demonstrating that the process of fermentation was due to living organisms, and that living organisms were also certainly the cause of some, and probably all, the zymotic diseases (as the communicable diseases were known). ${ }^{179}$ The presence of organic matter in water, traditionally the lynch-pin of water quality, was deprived of much of its importance, except as it served to indicate the possible presence of living organisms endowed with virulent propensities. ${ }^{180}$ The impact of Pasteur's work on water analysis was delayed by the as yet unconfirmed link between micro-organisms and disease; and the limitations of analysis meant that there could still be no fixed standard for water purity. ${ }^{181}$ The disputes which raged about the subject of water analysis in England thus continued unabated for some years. In 1871, for example, Professor Parkes of the Army Medical School, described as "usable" water which Frankland thought unfit for human consumption; Bolton deplored the "too frequent and too imprecise" use of terms such as "living organism" and "moving organism"; and Dr Beale of King's College Hospital stated that small fragments of dead animal or vegetable matter placed in pure water and left for a few hours would result in the development of simple living organisms, which "cannot well be considered prejudicial to health". ${ }^{182}$ With this divergence of views, and the old controversy about the quality of company supplies, ill feeling was never far removed from the London water debates. Small wonder that William Iliff, who saw all these views and investigations as of equal value in tending to the ultimate benefit of the consumer, felt it necessary to deplore the "antagonism that

Institute and the Royal College of Chemistry (later the Royal School of Mines). J. A. Wanklyn (1834-1906), analytical chemist, Professor of Chemistry at the London Institute, 1863-1870. William Odling FRS, Professor of Chemistry at Oxford University. Sir William Crookes FRS; C. Meymott Tidy (1843-1892), Professor of Chemistry and Forensic Medicine at the London Hospital, Medical Officer of Health for Islington.

176 Medical Officer's annual report, Newington, 1881-2, p. 7.

177 Ibid., 1883-4, p. 4.

178 J. A. Wanklyn and E. T. Chapman, Water analysis, London, 1868.

179 Percy Frankland, Micro-organisms in water, London, 1894, pp. ix-x.

100 Ibid.

181 Robert Koch isolated the anthrax bacillus in 1877 , but it was not until he succeeded in isolating the tuberculosis bacillus in 1882 that the existence of such organisms began to be widely accepted. See C. E. A. Winslow, The conquest of epidemic disease, 2nd ed., Madison and London, University of Wisconsin Press, 1980, pp. 298-301, 308-310.

182 Medical officer's annual report, Newington, 1871-2, p. 35. 


\section{Water and the search for public health in London}

seems inseparable from all inquiries as to the efficiency or otherwise of the arrangements of the Water Companies". ${ }^{183}$

It was not until Robert Koch published his methods of bacteriological study in 1881 that a uniform standard of analysis and water quality became possible. Koch's gelatine process of water examination was first introduced into England in 1885, 184 and the Thames and Lea waters were bacteriologically investigated at the instigation of the Local Government Board between 1885 and 1888. ${ }^{185}$ The result of this inquiry astonished the sanitary reformers, for it revealed that sand filtration removed at least ninety-five per cent of the micro-organisms present in water, according to the state of the filter bed. ${ }^{186}$ The remaining five per cent or less of organisms still presented a problem, however, and many people were finally convinced that London could only be provided with a medically satisfactory water supply by seeking an alternative source. ${ }^{187}$ Although deep wells were providing an increasing percentage of the city's supply (12.46 per cent in 1888 as against seven per cent in 1866), the rivers still constituted the major source. ${ }^{188}$ While other sources were under consideration, and argument continued as to the danger represented by the five per cent of remaining microorganisms, guidance was given by Koch's declaration that potable water should contain not more than 100 microbes per cubic centimetre. ${ }^{189}$ This gave medical officers an authoritative standard against which to measure company water. It was a more generous estimate than the old ideal standard of complete purity, but the condition of company water was still found to vary considerably according to the time of year. The Chelsea Company's count, for example, averaged fifty-six microbes per cubic centimetre, but varied from 232 in February to four in October. ${ }^{190}$ If such results were not always reassuring, medical officers could now form their own opinions about the local company water by using Koch's gelatine-plate culture, rather than having to interpret the conflicting opinions of the chemical experts. ${ }^{191}$

The establishment of a scientific basis of water analysis in the later 1880s stimulated increased attention to the other perennial grievance against the water companies: intermittent supply. From the earliest days of their appointment, the London medical officers had been pressing for the extension of the constant supply system to all dwellings in the city. ${ }^{192}$ Although provision had been made for this under the Waterworks Clauses Act 1847, the situation was still far from satisfactory in 1890. The slow spread of the constant system has generally been ascribed to the parsimony and self-interest

\footnotetext{
183 Ibid.

14 Frankland, op. cit., note 179 above, p. 119.

is Ibid., pp. 89-90, 120-124. I have been unable to trace the reports of this inquiry among the printed parliamentary papers.

${ }_{186}$ Frankland, op. cit., note 179 above, pp. 120, 124.

187 The London County Council, for example, planned to supply the whole of London with water brought from the Welsh hills. W. A. Robson, The government and misgovernment of London, London, Allen \& Unwin, 1939, p. 114.

128 Bolton and Scratchley, op. cit., note 136 above, p. 20. By 1954, the Thames provided sixty-nine per cent of London's water; the Lea, fifteen per cent; and the deep wells sixteen per cent, Dickinson, op. cit., note 9 above, p. 129.

${ }^{169}$ Medical Officer's annual report, Chelsea, 1895, p. 11.

190 Ibid.

191 Medical Officer's annual report, St George-the-Martyr, 1892, p. 25.

192 Camberwell Vestry Minutes, 4 June 1856.
} 


\section{Anne Hardy}

of the water companies, ${ }^{193}$ and though there may be justice in this, there were other factors involved. The London leasehold system was one major element, for although the companies were obliged to give a constant supply where the metropolitan authority requested it, in practice such requests were rare. ${ }^{194}$ The arrangement was an expensive one, because in accordance with the law the prospective tenant had to provide a domestic cistern and fittings to meet the company regulations. ${ }^{195}$ Where small landlords were responsible for a number of houses, and particularly where a poor class of property was involved, the capital investment required commonly outweighed any subsequent benefits that might be derived from a higher rental, even supposing the imposition of an increase in rental was feasible. Arrangements had also to be made with the local authority, under whose supervision alone the roadway and pavements might be broken up for the necessary connexion with the main to be laid. Finally, in the poorest quarters of the city, inhabited by those problem tenants whose sanitary requirements were in the public health view the most urgent, the landlord's investment was constantly at risk: taps, pipes, and other sanitary fittings were items of value in the scrap-metal market. ${ }^{196}$ In such circumstances, the sympathies of many medical officers lay with the landlords, and they were unwilling to force the extension of constant supply. ${ }^{197}$ By 1890 , therefore, although the constant supply system was certainly more widespread than it had been forty-five years earlier, much still remained to be done.

TABLE II: HOUSES IN LONDON ON THE CONSTANT SUPPLY SYSTEM, 31 MARCH $1891^{198}$

Company

New River

Grand Junction

Middlesex

East London

North of Thames

Per cent of
houses on constant
44
72
37
96

54.4

\section{Company}

Chelsea

Southwark

Kent

Lambeth

South of Thames

\section{Per cent of houses on constant}

23

76

57

53

62

Total average for London: 57.25 per cent on constant supply

At about this time also, doubts began to arise concerning the storage capacity of the companies. Initially, this concern emerged because of the continuing turbidity of supply, especially in the autumn and spring months, when the Thames was liable to flood. When this happened, quantities of topsoil and manure were washed downstream. This problem became prominent when in 1891, because of heavy

\footnotetext{
${ }^{193}$ This view of the matter was engraved on the public consciousness by LCC propaganda during the 1890s. For an alternative argument, professedly disinterested, and highly critical of the LCC's motives, see Arthur Shadwell, The London water supply, London, Longman, 1899.

194 Metropolis Water Act 1871, 34 \& 35 Vict. c 113, section 8. However, if two months after the application, less than four-fifths of the premises in the district did not have the required fittings, the company's obligation lapsed. Section 10. Levels of local activity in the matter are suggested by the proportion of houses on constant in the various districts in 1891. See Table I, p. 270.

195 Metropolis Water Act 1871 , Section 10.

196 Medical Officer's annual report, Camberwell, 1883-4, pp. 159-160.

197 Ibid.

196 London County Council, minutes of proceedings, 23 June 1891, p. 664.
} 


\section{Water and the search for public health in London}

flooding of the Thames and Lea in the summer and autumn, and dense smoke fogs which interfered with the companies' operations early in the year, there was exceptional pollution of the supply. Frankland observed that water "of such bad quality, as regards organic matter in solution, has rarely been delivered by the companies in the last 26 years". ${ }^{199}$ Although the water companies were by this date both storing (to allow settlement of suspended deposits) and filtering their supplies before passing them on to the consumer, it was evident that their storage facilities were not extensive enough to cope with such extraordinary conditions. The storage capacity of various companies in 1891 was: the Chelsea Company, 14.1 days' supply; the West Middlesex, 7.4; the Lambeth, 7; the Grand Junction, 3.5; the Southwark and Vauxhall, 2.7. ${ }^{200}$ When the "raw" water was so grossly polluted, the length of time required to make it drinkable exceeded the ratio of demand to storage, and the companies thus failed to supply water that was either pleasant or, indeed, safe. ${ }^{201}$ Nevertheless, Frankland's report for 1890, in which the analyses of that year were compared with those of 1868 , strikingly demonstrated the great improvement in filtration which the companies had effected since he first began examining their supplies. ${ }^{202}$ (See also Table III.)

The doubts about the companies' storage capacity increased as the new London County Council began to apply pressure for the universal extension of the constant service in the early 1890s. In its first two years, the LCC contented itself with exercising its power as metropolitan authority, under the Metropolis Water Act 1871, of applying to a water company to give constant supply in those cases where a vestry or district board requested it to do so. Although water supply had been a political issue in London since 1870, and although the new Council came to power determined to wrest the water companies' undertakings from them, ${ }^{203}$ it seems that politics did not dictate the Council's decision, in 1891, to take the initiative into its own hands, and to exercise its power throughout the county of London. In spite of the strong social improvement/public health motive long associated with constant water supply, the impetus for this decision came not from the Council's Sanitary Committee, but from the Fire Brigade Committee, which had experienced difficulty in obtaining water to extinguish fires in the Strand district. ${ }^{204}$ Some initial difficulties were met with in putting the scheme into effect, notably from the Chelsea Company, ${ }^{205}$ but by 1899 , the LCC had achieved one long-desired sanitary object: constant water supplied to all houses in the county of London area.

During the course of the 1890 s, however, further weaknesses were revealed in the

\footnotetext{
${ }^{199}$ Twenty-first annual report of the Local Government Board, BPP 1892 XXX-VIII, appendix B no. 53 , p. 251. There was, nevertheless, no abnormal sewage contamination. The greater part of the contaminating organic matter was derived from vegetable sources.

200 Medical Officer's annual report, Chelsea, 1891, p. 133.

201 Ibid.

${ }^{202}$ Twentieth annual report of the Local Government Board, BPP 1890-91 XXXIII appendix B, p. 362.

${ }^{203}$ Mukhopadhyay (1972), op. cit., note 111 above, p. 89. Wohl, op. cit., note 125 above, pp. 111 , states that there was no great philosophical debate over municipal purchase of private water companies. This was less true for London, see ibid.; also Shadwell, op. cit., note 193 above; and Nash, op. cit., note 210 below; for contemporary debate.

${ }^{204}$ LCC, minutes of proceedings, 23 June 1891, p. 664.

205 Ibid., 29 March 1892, p. 284.
} 
TABLE III: AMOUNT OF ORGANIC MATTER IN WATER DELIVERED IN LONDON: 1868 TAKEN AS BASE FIGURE

\begin{tabular}{|c|c|}
\hline Year & matter \\
\hline 1868 & 1,000 \\
\hline 1869 & 1,016 \\
\hline 1870 & 795 \\
\hline 1871 & 928 \\
\hline 1872 & 1,243 \\
\hline 1873 & 917 \\
\hline 1874 & 933 \\
\hline 1875 & 1,030 \\
\hline 1876 & 903 \\
\hline 1877 & 907 \\
\hline 1878 & 1,056 \\
\hline 1879 & 1,165 \\
\hline 1880 & 1,245 \\
\hline 1881 & 993 \\
\hline 1882 & 1,033 \\
\hline 1883 & 850 \\
\hline 1884 & 723 \\
\hline 1885 & 839 \\
\hline 1886 & 756 \\
\hline 1887 & 690 \\
\hline 1888 & 722 \\
\hline 1889 & 677 \\
\hline 1890 & 680 \\
\hline 1891 & 1,002 \\
\hline 1892 & 831 \\
\hline 1893 & 762 \\
\hline 1894 & 955 \\
\hline 1895 & 731 \\
\hline 1896 & 797 \\
\hline 1897 & 735 \\
\hline 1898 & 663 \\
\hline 1899 & 821 \\
\hline 1900 & 749 \\
\hline 1901 & 818 \\
\hline 1902 & 822 \\
\hline
\end{tabular}

\section{Amount of organic}

matter

1,000

795

928

243

933

, 030

903

907

1,056

1,245

993

033

723

839

756

690

677

680

002

831

762

731

797

735

663

821

818

822

Source: Thirty-seventh annual report of the Local Government Board BPP 1903 XXIV, p. 265.

company system of water administration, which helped to strengthen the case for public ownership, and uniform regulation of water provision. These weaknesses were brought to light by the water famines that occurred in the East London Company district in the years 1895,1896 , and 1898. The winter of 1894-5 was particularly severe, and most of the companies suffered interruptions of supply through frozen mains. ${ }^{206}$ The following summer was particularly dry, and several of the companies were unable to maintain supply. In Camberwell, for example, there were complaints against both the Southwark and the Lambeth companies because of supply failure, ${ }^{207}$

206 Medical Officer's annual report, Fulham, 1896, p. 39.

207 Camberwell Vestry Minutes, 2 April 1895. 


\section{Water and the search for public health in London}

but the East London, virtually the whole of whose area was on constant supply, suffered the most severely. With the extension of constant supply increasing demand, and with a series of exceptionally hot summers resulting in both the Thames and Lea running abnormally low, ${ }^{208}$ water failures were again experienced in 1896 and 1898. In East London, the problem was compounded by local sanitary regulations which, with the introduction of constant service, had made away with domestic storage cisterns, on the grounds that they were insanitary and, with constant supply, mercifully unnecessary. When the mains were cut off, therefore, not the smallest supply of water remained for emergency use. ${ }^{209}$ Although the East London Company was on each occasion bailed out of its immediate difficulties by the other companies, these in so doing placed a strain on their own supplies. ${ }^{210}$ It was not until after 1898 , when disaster struck in a drought unparalleled for eighty-six years, that the companies obtained powers for adequate communicating mains. ${ }^{211}$

The pollution experience of 1891 and the later water failures demonstrated the continuing vulnerability of London's water supply. Although the enormous improvements in both sewerage and water supply which had taken place since $c .1855$ were widely seen as responsible for the marked decline in adult mortality from water-borne disease during that period, ${ }^{212}$ such incidents as the outbreak of cholera on the Continent in 1892-92 produced some sanitary anxiety. ${ }^{213}$ Concern over the sanitary aspects of the water supply was compounded by other events in the 1890s: the introduction of scientific analysis; the extension of constant supply; the demonstrated flaws in local sanitary regulations with regard to water; the continued remarkable growth of population in the capital which, it was feared, would soon strain the companies' resources beyond their capability; political developments at government level and within the LCC. The old private local system of water provision in the capital was finally destroyed by this combination of developments. ${ }^{214}$ In 1904, the eight remaining water companies were taken over by the Metropolitan Water Board, which henceforth managed all the water undertakings in the London area. Yet the policies adopted by the new management were far from revolutionary. Until after the First World War, the Metropolitan Water Board continued to pursue expansion along the lines pro-

208 Dickinson, op. cit., note 9 above, p. 110. For rainfall statistics see John Glasspoole, 'Rainfall over the British Isles 1870-1939', Quart. J. Meteorol. Soc., 1941, 67: 5-9.

209 Medical Officer's annual report, Chelsea, 1899, p. 114.

${ }^{210}$ Dickinson, op. cit., note 9 above, p. 110. For a critical view of the Company's performance, see Vaughan Nash, 'The East London Water Company', Contemporary Review, October 1898, 474-479. Nash was significantly uncritical of the LCC's policy.

${ }^{211}$ Metropolis Water Act 1899, 62 Vict. c 7. The preamble stated: "An act to enable and require the metropolitan water companies to supply each other with water in cases of emergency."

${ }^{212}$ T. McKeown, The modern rise of population, London, Edward Arnold, 1976, pp. 120-121; Medical Officer's annual report, Local Government Board BPP 1897 XXXVII, p. 14.

${ }^{213}$ The Metropolitan Asylums Board, which ran London's infectious disease hospitals, issued instructions on cholera prevention in 1892; the Local Government Board in July 1893. The local medical officers of health were largely unperturbed; most mention the instructions in passing, while a few express their belief that an epidemic was unlikely, e.g., Medical Officer's annual report, Camberwell, 1892-3, p. 305. There was some popular anxiety, Vestry annual report, Newington, 1893-4, p. 212. The LCC's medical officer reposed almost complete confidence in the "excellent arrangements" of the Port of London Sanitary Authority, see his Annual report, 1892, p. 26.

${ }^{214}$ For the political manoeuvres involved in achieving the establishment of the Metropolitan Water Board, see Mukhopadhyay (1972), op. cit., note 111 above, ch. 4. 


\section{Anne Hardy}

jected by its predecessors. ${ }^{215}$ The quality of the supply also remained much the same. Although the chlorine process of water purification (by which all traces of organic contamination remaining after filtration could be removed from water) was first used successfully in England in 1897,216 public prejudice against the introduction of chemicals into the water supply ${ }^{217}$ hindered its application to domestic supplies until about 1920. It was not until 1921 that London's water supply was considered safe enough for the Board of Trade to abolish the post of Metropolitan Water Examiner. ${ }^{218}$

${ }^{215}$ Dickinson, op. cit., note 9 above, p. 128.

${ }^{216}$ Report on typhoid fever at Maidstone, BPP 1898 XI, pp. 99-617: p. 10; Royal Commission on Sewage Disposal, fifth report, appendix IV, BPP 1908 LV, pp. 681-748.

${ }^{217}$ A. C. Houston, Studies in water supply, London, Macmillan, 1913, pp. 64-65.

218 Dickinson, op. cit., note 9 above, p. 123. The Metropolitan Water Board appointed its own water examiner in 1905 , and this post continued in existence. 